\title{
Localised mixing and heterogeneity in the plankton food web in a frontal region of the Sargasso Sea: implications for eel early life history?
}

\author{
Katherine Richardson ${ }^{1, *}$, Jørgen Bendtsen ${ }^{2}$, Jens Tang Christensen ${ }^{3}$, \\ Mohamed Adjou ${ }^{1}$, Maren Moltke Lyngsgaard ${ }^{1}$, Karen Marie Hilligsøe ${ }^{3}$, \\ Jens B. Pedersen ${ }^{3}$, Torben Vang ${ }^{3}$, Morten Holtegaard Nielsen ${ }^{4}$ \\ ${ }^{1}$ Center for Macroecology, Evolution and Climate. Universitetsparken 15, 2100 Copenhagen, Denmark \\ ${ }^{2}$ ClimateLab, Symbion Science Park, Fruebjergvej 3, Box 98, 2100 Copenhagen, Denmark \\ ${ }^{3}$ Department of Bioscience, Aarhus University, Ole Worms Allé 1, 8000 Aarhus C, Denmark \\ ${ }^{4}$ Arctic Technology Centre, Department of Civil Engineering, Technical University of Denmark, Kemitorvet, Building 204, \\ 2800 Kgs. Lyngby, Denmark
}

\begin{abstract}
Previous studies have demonstrated that patches of eel larvae are found in the frontal region of the Subtropical Convergence Zone (STCZ), but to date no clear evidence of why this region might confer advantage to the larvae has been presented. This study demonstrates that there may be localized patches within a frontal region in the STCZ in the Sargasso Sea that experience elevated vertical mixing and an associated vertical flux of nutrients. This localized vertical mixing was suggested by a group of stations within the frontal region that exhibited a greater similarity (Jaccard index) between the diatom communities at $10 \mathrm{~m}$ and $>100 \mathrm{~m}$ (in the deep chlorophyll maximum, DCM) than in other parts of the frontal region. Thorpe displacements supported the hypothesis of elevated mixing intensities around these stations, as did vertical mixing rates inferred from stratification and vertical current shear calculated from acoustic Doppler current profiler (ADCP) measurements. Combining these mixing estimates with vertical nutrient gradients suggests that nutrient fluxes to the euphotic zone at these mixing sites may be an order of magnitude greater than elsewhere in the frontal region. This mixing may influence the plankton food web, as indicated by elevated values/concentrations of (1) primary production, (2) variable fluorescence $\left(F_{\mathrm{v}} / F_{\mathrm{m}}\right)$ and (3) total seston. In addition, the fraction of the total biomass of both copepods and nauplii found closest to the DCM in the frontal region correlated with the stratification (Brunt-Väisälä frequency), with the greatest fractions found below $75 \mathrm{~m}$ at the most weakly stratified stations. While this study cannot directly link these observations to eel larvae ecology, Munk et al. (2010; Proc R Soc B 277:3593-3599) reported that eel larvae were most abundant at locations where we found evidence for elevated vertical mixing.
\end{abstract}

KEY WORDS: Plankton $\cdot$ Eel larvae $\cdot$ Sargasso Sea $\cdot$ Mixing $\cdot$ Primary production

\section{INTRODUCTION}

The frontal region in the Subtropical Convergence Zone (STCZ) in the southern Sargasso Sea is interesting in that patches of American eel Anguilla rostrata and European eel Anguilla anguilla larvae have been found in several studies (e.g. Kleckner et al. 1983, Kleckner \& McCleave 1988, Munk et al. 2010). However, reasons for this association are not clear. One hypothesis is that this frontal zone might comprise more rewarding feeding grounds for the larvae than surrounding waters. However, two studies (Andersen 
et al. 2011, Riemann et al. 2011) carried out concomitantly with the Munk et al. (2010) study failed to identify significant differences in either primary or secondary production between frontal and non-frontal waters - although the Andersen et al. (2011) study did suggest a greater abundance of some zooplankton forms in the frontal region than elsewhere.

Thus, the current state of understanding regarding the distribution of eel larvae in the Sargasso Sea, at the time of the Munk et al. (2010) study, was that they were only found in the frontal region, that they were patchily distributed, and that there was no indication of increased primary or secondary plankton production that would suggest better feeding conditions in the frontal region for eel larvae. The present study further extends the understanding of the Sargasso Sea ecosystem at the time of the Munk et al. (2010) study by examining the frontal region itself for potential heterogeneity in physical and biological characteristics in the water column.

The front region in question is located in the STCZ, a transition zone between $25^{\circ} \mathrm{N}$ and $32^{\circ} \mathrm{N}$ in the North Atlantic subtropical gyre separating relatively cold waters in the area (dominated by the Westerlies) from warm waters in the trade wind region (Leetmaa \& Voorhis 1978). Results from the MODE experiments (MODE group 1978) have shown that the STCZ in the Sargasso Sea can be characterized by mixing between the cold and warm water masses in the form of north-south oriented plumes with spatial scales of about $200 \mathrm{~km}$, where smaller scale frontal structures with spatial scales of about $10 \mathrm{~km}$ appear on the edges of these plumes.

The mesoscale variability associated with the frontal structures is characterized by temperature gradients of about $0.1^{\circ} \mathrm{C} \mathrm{km}^{-1}$, depth ranges of the order of $100 \mathrm{~m}$ and relatively short temporal scales of about 3 to $5 \mathrm{~d}$. Satellite-derived estimates of frontal structure and locations confirm a relatively high probability of front occurrences in the Sargasso Sea region from $25^{\circ}$ to $35^{\circ} \mathrm{N}$ and $74^{\circ}$ to $55^{\circ} \mathrm{W}$, with significantly increased frontal activity in the spring period (Ullman et al. 2007).

The presence of an STCZ and an associated eastward-flowing subtropical countercurrent are features typical of the northern subtropical gyres in both the Atlantic and the Pacific. The countercurrent in the gyres has been found to be associated with interactions between general wind-driven circulation (from the Westerlies and trades), thermal stratification (Cushman-Roisin 1984), and mixed layer depth distribution (Kubokawa \& Inui 1999) of the upper ocean. High-resolution studies of the small-scale frontal structures in the Northern Pacific STCZ revealed intense mixing and interleaving on spatial scales of $\sim 5 \mathrm{~km}$ in the upper $150 \mathrm{~m}$ of the water column (Shcherbina et al. 2009). The STCZ is therefore a consistent feature of the subtropical gyres. It is an area characterized by deep small-scale frontal dynamics on relatively small spatial and temporal scales and these dynamics have the potential of affecting biogeochemical cycling significantly through increased mixing of nutrients.

The present study is based on data collected on the same cruise as the Munk et al. (2010), Andersen et al. (2011) and Riemann et al. (2011) studies. We hypothesized that the frontal dynamics described above might potentially create heterogeneity in the plankton production characteristics within the frontal region. If this were the case, then comparing characteristics of the frontal region as a whole with non-frontal regions would not necessarily provide a representative description of the potential of this region to meet the feeding needs of higher tropic levels. We conclude that localized vertical mixing leads to enhanced nutrient delivery to the photic zone at specific sites within the frontal region, and that this nutrient delivery may stimulate the plankton food web at those locations. Although our data do not provide the basis to identify a direct link between this apparent stimulation at the base of the plankton food web and feeding by eel larvae, we do note that the greatest concentrations of eel larvae recorded by Munk et al. (2010) were found in an area of the frontal region where this enhanced nutrient mixing is inferred.

\section{MATERIALS AND METHODS}

Study area. The study was part of the Danish 'Galathea 3' Expedition (www.galathea3.dk) that circumnavigated the globe in 2006 and 2007. Sampling in the Sargasso Sea took place from 29 March to 10 April 2007. Multi-disciplinary studies were carried out, although the main purpose was mapping the distributions of eel larvae (Munk et al. 2010). CTD and water collection were generally carried out during daylight hours (Table 1). Three north-south transects along the longitudes $64^{\circ} \mathrm{W}$ (Transect 1 ), $67^{\circ} \mathrm{W}$ (Transect 2) and $70^{\circ} \mathrm{W}$ (Transect 3 ) were sampled (Fig. 1). Transect positions were chosen on the basis of the positions of sea surface temperature (SST) isotherms prior to the sampling period and all transects provided samples from both in and outside of the frontal area. 
Table 1. Station list for the 3 transects with positions and time of measurements (UTC). Stations where CTD, diversity, biology (i.e. primary production [PP], chlorophyll a) nutrients were measured are indicated with an ' $\mathrm{x}$ '

\begin{tabular}{|c|c|c|c|c|c|c|}
\hline $\begin{array}{l}\text { Station } \\
\text { ID }\end{array}$ & $\begin{array}{l}\text { Lat. } \\
\left({ }^{\circ} \mathrm{N}\right)\end{array}$ & $\begin{array}{l}\text { Long. } \\
\left({ }^{\circ} \mathrm{W}\right)\end{array}$ & $\begin{array}{c}\text { Date } \\
\mathrm{mm} / \mathrm{dd} / \text { yyyy }\end{array}$ & $\begin{array}{l}\text { Time } \\
\text { (UTC) }\end{array}$ & $\begin{array}{c}\text { CTD \& } \\
\text { diversity }\end{array}$ & $\begin{array}{c}\text { PP, } \\
\text { chl a \& } \\
\text { nutrients }\end{array}$ \\
\hline \multicolumn{7}{|c|}{ Transect 1} \\
\hline $17-1$ & 19.00 & 64.00 & 03/29/2007 & 12:08 & $\mathrm{x}$ & $\mathrm{x}$ \\
\hline $17-5$ & 20.50 & 64.01 & $03 / 29 / 2007$ & $22: 48$ & $\mathrm{x}$ & \\
\hline $17-10$ & 22.04 & 64.00 & 03/30/2007 & $11: 04$ & $\mathrm{x}$ & $\mathrm{x}$ \\
\hline $17-12$ & 23.00 & 64.00 & $03 / 30 / 2007$ & $16: 37$ & $\mathrm{x}$ & \\
\hline $17-15$ & 24.00 & 64.00 & $03 / 30 / 2007$ & $23: 54$ & $\mathrm{x}$ & \\
\hline $17-18$ & 24.50 & 64.00 & 03/31/2007 & $05: 47$ & $\mathrm{x}$ & \\
\hline $17-22$ & 25.25 & 64.00 & $03 / 31 / 2007$ & $22: 57$ & $\mathrm{x}$ & $\mathrm{x}$ \\
\hline $17-25$ & 26.00 & 64.00 & $04 / 01 / 2007$ & 06:00 & $\mathrm{x}$ & \\
\hline $17-28$ & 26.50 & 64.00 & $04 / 01 / 2007$ & $13: 01$ & $\mathrm{x}$ & $\mathrm{x}$ \\
\hline $17-33$ & 27.00 & 64.00 & $04 / 01 / 2007$ & $20: 39$ & $\mathrm{x}$ & \\
\hline $17-36$ & 27.33 & 64.00 & $04 / 02 / 2007$ & 01:33 & $\mathrm{x}$ & $\mathrm{x}$ \\
\hline $17-43$ & 27.66 & 64.00 & $04 / 02 / 2007$ & $14: 56$ & $\mathrm{x}$ & $\mathrm{x}$ \\
\hline $17-46$ & 28.00 & 64.00 & $04 / 02 / 2007$ & $19: 42$ & $\mathrm{x}$ & \\
\hline $17-49$ & 28.33 & 64.00 & $04 / 03 / 2007$ & $19: 42$ & $\mathrm{x}$ & \\
\hline $17-52$ & 28.66 & 64.00 & 04/03/2007 & $06: 30$ & $\mathrm{x}$ & \\
\hline \multicolumn{7}{|c|}{ Transect 2} \\
\hline $17-55$ & 28.50 & 67.00 & 04/03/2007 & $20: 28$ & $\mathrm{x}$ & $\mathrm{x}$ \\
\hline $17-57$ & 27.75 & 67.00 & $04 / 03 / 2007$ & $01: 52$ & $\mathrm{x}$ & \\
\hline $17-59$ & 27.00 & 67.00 & 04/03/2007 & 07:06 & $\mathrm{x}$ & \\
\hline $17-61$ & 26.50 & 67.00 & $04 / 04 / 2007$ & $11: 25$ & $\mathrm{x}$ & $\mathrm{x}$ \\
\hline $17-63$ & 26.00 & 67.00 & $04 / 04 / 2007$ & $16: 07$ & $\mathrm{x}$ & \\
\hline $17-65$ & 25.66 & 67.00 & $04 / 04 / 2007$ & $20: 05$ & $\mathrm{x}$ & \\
\hline $17-68$ & 25.33 & 67.00 & $04 / 05 / 2007$ & 00:58 & $\mathrm{x}$ & \\
\hline $17-72$ & 25.00 & 67.00 & $04 / 05 / 2007$ & $08: 26$ & $\mathrm{x}$ & $\mathrm{x}$ \\
\hline $17-74$ & 24.50 & 67.00 & $04 / 05 / 2007$ & $16: 00$ & $\mathrm{x}$ & \\
\hline \multicolumn{7}{|c|}{ Transect 3} \\
\hline $17-79$ & 24.99 & 70.00 & $04 / 06 / 2007$ & 08:31 & $\mathrm{x}$ & $\mathrm{x}$ \\
\hline $17-80$ & 25.50 & 70.00 & $04 / 06 / 2007$ & $11: 50$ & $\mathrm{x}$ & \\
\hline $17-83$ & 26.00 & 70.00 & $04 / 06 / 2007$ & $18: 15$ & $\mathrm{x}$ & \\
\hline $17-87$ & 26.50 & 70.00 & $04 / 07 / 2007$ & $02: 37$ & $\mathrm{x}$ & \\
\hline $17-94$ & 27.03 & 70.00 & $04 / 07 / 2007$ & $16: 02$ & $\mathrm{x}$ & $\mathrm{x}$ \\
\hline $17-95$ & 27.50 & 70.00 & $04 / 07 / 2007$ & 19:08 & $\mathrm{x}$ & \\
\hline $17-99$ & 28.00 & 70.00 & $04 / 08 / 2007$ & 03:02 & $\mathrm{x}$ & \\
\hline $17-103$ & 28.99 & 70.00 & 04/08/2007 & $12: 36$ & $\mathrm{x}$ & $\mathrm{x}$ \\
\hline $17-107$ & 30.00 & 70.00 & $04 / 08 / 2007$ & $20: 32$ & $\mathrm{x}$ & \\
\hline $17-111$ & 32.51 & 70.00 & $04 / 09 / 2007$ & $14: 00$ & $\mathrm{x}$ & $\mathrm{x}$ \\
\hline
\end{tabular}

Water column characteristics. Conductivity, temperature (2 separate $\mathrm{C}$ - and $\mathrm{T}$-sensors), and pressure were measured using a Seabird Instruments 911 series. The instruments were attached to a rosette of 12 Niskin bottles (30 1), a fluorometer (SCUFA), light meters (Biospherical) and 2 oxygen sensors (SBE43). All instruments were calibrated and data qualitycontrolled before use. Samples were taken from selected depths for oxygen calibration (Winkler), and salinity calibration (PortaSal). Measurements made with the SCUFA fluorometer mounted with the CTD were subsequently calibrated against chlorophyll $a$ concentrations $\left(r^{2}=0.79, \mathrm{n}=17\right)$ from water samples (GF/F filtered). The filters were stored in glass vials with $5 \mathrm{ml} 96 \%$ ethanol and frozen at $-20^{\circ} \mathrm{C}$. Prior to analysis, the samples were extracted for 6 to $24 \mathrm{~h}$ in darkness at room temperature. The samples were measured on a TD-700 fluorometer (Turner Designs), which was calibrated against a pure chlorophyll a standard. Chlorophyll concentration was determined after Method 445.0 by the US Environmental Protection Agency as suggested by Turner Designs (Arar \& Collins 1997). Samples for inorganic nutrients, variable fluorescence, primary production, and phytoplankton species composition were only collected at every second or third CTD station (Fig. 1, Table 1).

CTD data analysis. Pressure measurements were averaged with a time constant of $0.15 \mathrm{~s}$, corresponding to a vertical scale of $8 \mathrm{~cm}$ for a descent rate of $0.5 \mathrm{~m} \mathrm{~s}^{-1}$ (i.e. a scan rate of $24 \mathrm{~Hz}$ for the SBE9+ instruments in the CTD system). The 2 conductivity and temperature sensors were only analysed for the downcasts and reversals were removed by only considering measurements with a minimum CTD velocity of $0.1 \mathrm{~m} \mathrm{~s}^{-1}$. Finally, the CTD data were bin-averaged in intervals of $0.5 \mathrm{dbar}$.

Determination of inorganic nutrients. At each station, seawater from the DCM and the standard sampling depths of 10, 30, 60, 100,200 and $400 \mathrm{~m}$ was tapped and immediately frozen. The subsequently filtered seawater (Millipore Millex-GP Hydrophilic PES0 $0.22 \mathrm{~mm}$ ) was analyzed for nitrate, nitrite, phosphate, ammonium and silicate by wet-chemistry methods according to Grasshoff et al. (1983) with a SanPlus System Scalar auto-analyser at the National Environmental Research Institute (NERI), University of Aarhus, Denmark. The detection limits were $0.06,0.1,0.04,0.3$ and $0.2 \mu \mathrm{mol} \mathrm{kg}{ }^{-1}$ for $\mathrm{PO}_{4}$, $\mathrm{NO}_{3}, \mathrm{NO}_{2}, \mathrm{NH}_{4}$ and silicate, respectively. A detailed description of the distribution of inorganic nutrients is given in Riemann et al. (2011). Therefore, only nutrient information relevant for the current analyses is presented here.

Primary production. Samples were collected from surface waters $(10 \mathrm{~m})$ and the DCM; primary production was determined using the carbon-14 method modified after Steemann Nielsen (1952). The actual method applied is described in detail in Hilligsøe et al. (2011). Briefly, after the addition of ${ }^{14} \mathrm{C}$, samples 


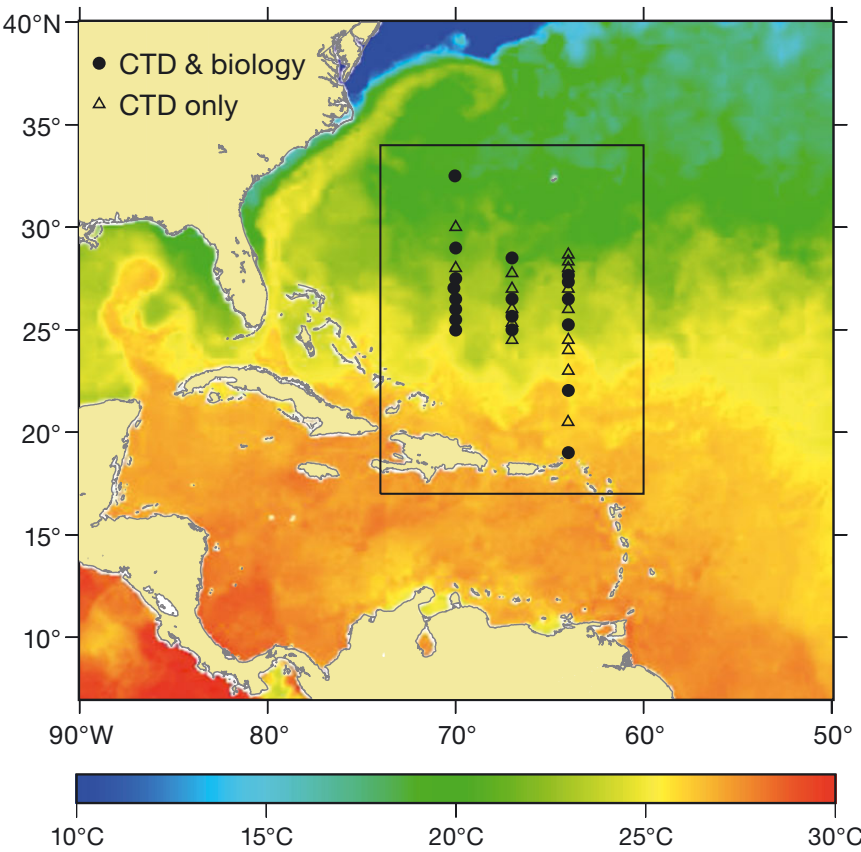

Fig. 1. Position of stations in the Sargasso Sea where both CTD and biology measurements $(\bullet)$ and where only CTD $(\Delta)$ measurements were made. Background color depicts satellite-derived sea surface temperature (SST) from 31 March 2007. The rectangle shows the area of study, shown in detail in Fig. 5

were incubated at a range of photon flux densities for $2 \mathrm{~h}$. In this manner, photosynthesis (P) vs. light (E) curves were established for both the surface and DCM populations. These were applied to the hourly average of the light estimated to be found at each depth of the water column in $1 \mathrm{~m}$ depth intervals throughout the day (applying the light attenuation coefficient recorded at the specific station and assuming average hourly light averages for light incident upon the surface based on the actual light measured in the area during the week of sampling).

The P vs. E characteristics for the surface population were assumed to apply for populations down to the DCM and the DCM characteristics for all deeper depths. A biomass correction was, however, applied using the chlorophyll estimates made from fluorescence recorded at $1 \mathrm{~m}$ depth intervals and assuming the actual amount of photosynthesis occurring to be linearly related to the chlorophyll concentration. Total particulate primary production was estimated both with (Platt et al. 1980) and without a correction for photoinhibition. Both the distribution pattern between stations and the magnitude of the estimated primary production were similar with and without the correction. The non-corrected estimates are reported here. Note that there are minor differences in the magnitude of the primary production estimates reported here and in Riemann et al. (2011) owing to differences in the method used to fit the curves to the P vs. E parameters between the 2 studies.

Phytoplankton community analysis. Samples for phytoplankton analysis were taken from Niskin bottles closed at the surface $(10 \mathrm{~m})$ and the DCM; depths varied between 100 and $140 \mathrm{~m}$. These were preserved in 11 brown glass bottles with acidified Lugol's solution (approximately $2 \%$ final concentration) for taxonomic determination of nano- and microplankton. Identification of the organisms present in this size fraction (> ca. $2 \mu \mathrm{m}$ ) was made using quantitative light microscopy according to Utermöhl (1958). Cell biovolumes were estimated from linear dimensions and calculated using appropriate geometric volume formulas. Carbon content was estimated using carbon to volume relationships given in Edler (1979). Analyses were carried out by Orbicon A/S (Aarhus, Denmark).

Jaccard Index. $J$ (Jaccard 1901) was calculated to determine the similarity between the diatom communities at $10 \mathrm{~m}$ and at the DCM at each sampled station. $J$ measures the similarity between 2 communities $C_{1}$ and $C_{2}$ and is calculated as:

$$
J=\frac{\alpha}{\alpha+\beta+\gamma}
$$

where $\alpha$ is the number of shared species in the communities $C_{1}$ and $C_{2}, \beta$ is the number of species present in community $C_{1}$ but absent in $C_{2}$, and $\gamma$ is the number of species present in community $C_{2}$ but absent from $C_{1} . J$ ranges from 0 (when $C_{1}$ and $C_{2}$ have no shared species) to 1 (when all species are shared). The diatom component of the plankton community was selected for the analysis as these organisms are comparatively easy to identify relative to the more dominant component comprised of small flagellates.

Zooplankton analysis. As a proxy for mesozooplankton distributions, the total abundance and biomass of calanoid and cyclopoid copepods down to $250 \mathrm{~m}$ were determined at 32 stations. Samples for determining the vertical distribution of metazooplankton $(>50 \mu \mathrm{m})$ were collected using a HydroBios MultiNet Midi. The MultiNet consists of 5 nets with a closing option for 4 of the nets. The MultiNet was lowered and hauled with speeds of $18 \mathrm{~m} \mathrm{~min}^{-1}$ and $10 \mathrm{~m} \mathrm{~min}^{-1}$, respectively. Samples were fixed in $4 \%$ formalin and stored at $5{ }^{\circ} \mathrm{C}$ prior to microscopic enumeration of copepods and nauplii.

At some stations, a single Multinet haul was made to $250 \mathrm{~m}$. At others, hauls were made in consecutive strata of the water column. When stratified sampling 
was carried out, the abundance and biomass to $250 \mathrm{~m}$ were calculated by multiplying the abundance/biomass per volume $\left(a_{\mathrm{i}}\right)$ for each stratum (i) down to $250 \mathrm{~m}$ by the height of the stratum $\left(h_{\mathrm{i}}\right)$ and subsequently taking the sum of these contributions. The average abundance/biomass in the water column was found by dividing the total abundance/biomass in the uppermost $250 \mathrm{~m}$ by $250 \mathrm{~m}$. Methods and length-weight relationships used to convert abundance to biomass are given in Andersen et al. (2011).

The fraction of copepods/nauplii beneath $75 \mathrm{~m}$ was defined as the abundance/biomass of copepods/ nauplii found in the interval from $75 \mathrm{~m}$ to $250 \mathrm{~m}$ divided by the total abundance/biomass of the copepods/nauplii under the same area of sea surface in the depth interval from 0 to $250 \mathrm{~m}$.

Thorpe displacements. Thorpe displacements are a measure of the length scale associated with instabilities in a vertical density profile, and it is assumed that the instability is due to overturning induced by turbulent eddies. The vertical displacement of water parcels by eddies causes instabilities in the CTD profiles and displacements are therefore representative of the eddy-induced vertical movement of water parcels from an initial stable stratification. Thus, Thorpe displacements can be related to the intensity of vertical turbulent mixing (Thorpe 1977). Thorpe displacements $(L)$ were determined by reordering the density profiles by applying a noise level of $\Delta \rho=10^{-3}$ $\mathrm{kg} \mathrm{m}^{-3}$ (Ferron et al. 1998). According to Galbraith \& Kelley (1996), the minimum thickness of resolvable overturn $\left(L_{\min }\right)$ can be estimated as $L_{\min }=2 g \Delta \rho /\left(N^{2}\right.$ $\rho_{0}$ ), where $g$ is the gravitional constant and $\rho_{0}$ is a reference density. A typical stratification frequency for intermediate depth levels at $150 \mathrm{~m}$ depth in the area was $N=0.008 \mathrm{~s}^{-1}$, corresponding to a minimum resolvable thickness of $0.3 \mathrm{~m}$. However, the bin-average of the CTD profile made a lower limit of about 0.5 to $1 \mathrm{~m}$ on the Thorpe scale displacements. Thorpe displacements were subsequently averaged over $5 \mathrm{~m}$ intervals.

ADCP measurements. Current velocities were measured by 2 downward-looking ADCPs from Teledyne RD Instruments: a $600 \mathrm{kHz}$ Workhorse Monitor and a $75 \mathrm{kHz}$ Workhorse Long Ranger. The 2 ADCPs had ranges of about $50 \mathrm{~m}$ and about $600 \mathrm{~m}$, respectively, where the upper part of the water column had to be blanked out. Data were collected using single pings and depth cells of $2 \mathrm{~m}$ and $16 \mathrm{~m}$, respectively. The velocity observations were referenced to earth by subtracting the vessel velocity, found using the bottom track of one or the other ADCP, where available, or calculated from GPS data, subjected to a $5 \mathrm{~s}$ moving average. There was good agreement between the measurements in the depth range 30 to $50 \mathrm{~m}$ where the 2 instruments overlapped. In the analysis below we considered the mixing below $50 \mathrm{~m}$ and therefore only data from the $75 \mathrm{kHz}$ sensor were used. In order to examine the velocity structure of the water column, the ADCP data collected at the time of CTD profiling were averaged over $1 \mathrm{~h}$ into one vertical velocity profile. This corresponds to averaging of about 900 independent observations.

Richardson number and vertical mixing. The Richardson number $(R i)$ describes the importance of stratification for damping vertical mixing compared to the vertical velocity shear which provides energy for turbulent motion. A large Richardson number indicates reduced mixing due to a relatively large stability in the water column and vice versa. The stratification is determined from the Brunt-Väisälä frequency $\left(N^{2}=-g / \rho \partial \rho / \partial z\right.$, where $g$ is the gravitational constant, $\rho$ is density and $z$ the vertical coordinate and the gradient is determined continuously over a $10 \mathrm{~m}$ interval). The density was determined from CTD measurements and the velocity shear $\left(S^{2}\right)$ was determined from the eastward $(u)$ and northward $(v)$ velocity components measured by the $75 \mathrm{kHz}$ ADCP sensor $\left[S^{2}=(\partial u / \partial z)^{2}+(\partial v / \partial z)^{2}\right]$. The Richardson number is defined as: $R i=N^{2} / S^{2}$. Empirical relationships have been established for calculating the vertical turbulent diffusion coefficient $\left(k_{\mathrm{v}}\right)$ from the Richardson number and we apply the KPP parameterisation after Pacanowski \& Philander (1981):

$k_{\mathrm{v}}=\frac{5 \times 10^{-3} \mathrm{~m}^{2} \mathrm{~s}^{-1}+(1+5 \times R i)^{2} \times 10^{-4} \mathrm{~m}^{2} \mathrm{~s}^{-1}}{(1+5 \times R i)^{3}}+10^{-5} \mathrm{~m}^{2} \mathrm{~s}^{-1}$

The parameterisation implies a minimum value of $k_{\mathrm{v}}$ of about $10^{-5} \mathrm{~m}^{2} \mathrm{~s}^{-1}$ for large Ri numbers, corresponding to typical values for the ocean interior, whereas small Ri numbers increase the mixing coefficient significantly. The KPP parameterisation has been found to provide a good estimate of the shearinduced vertical mixing intensities when compared to other methods (e.g. Cisewski et al. 2005).

Vertical nutrient flux. The vertical nutrient flux $\left(\mathrm{F}_{\mathrm{N}}\right)$ due to turbulent mixing was estimated as $\mathrm{F}_{\mathrm{N}}=$ $-k_{\mathrm{v}} \mathrm{DIN}_{\mathrm{z}}$, where $\mathrm{DIN}_{\mathrm{z}}$ was the vertical gradient of dissolved inorganic nitrogen (DIN); i.e. the sum of nitrate, nitrite and ammonium. The vertical gradient was estimated from observed values in a depth range below the turbulent mixed layer. The vertical nutrient fluxes were converted to carbon units (i.e. new production, sensu Dugdale \& Goering 1967) by applying a Redfield C:N ratio of $\eta=106: 16$, i.e. the carbon flux was determined as $F_{C}(D I N)=\eta F_{N}$. 
Variable fluorescence. Variable fluorescence normalised to maximum fluorescence yield in darkadapted populations $\left(F_{\mathrm{v}} / F_{\mathrm{m}}\right)$, an indicator for the potential for electron transport in Photosystem II (PSII), was determined on discrete samples (3 replicates) taken from selected depths in the water column. Samples were incubated in darkness for a minimum of $30 \mathrm{~min}$ in a thermally insulated container. $F_{\mathrm{v}} / F_{\mathrm{m}}$ was measured with a FastTracka fluorometer (Chelsea Instruments). We used a single turnover protocol with 30 sequences per acquisition, each including 100 saturation flashlets and 20 relaxation flashlets. The sequence interval was set to $1000 \mathrm{~ms} . F_{\mathrm{v}} / F_{\mathrm{m}}$ was calculated from a saturation phase fit and a relaxation phase fit following Kolber et al. (1998). Only measurements with a qualifying saturation phase and relaxation phase were included in the data set.

Stable isotope analyses. Bulk particulate matter (seston) was obtained by vertical hauls of a Multinet (Hydro-Bios) with $0.25 \mathrm{~m}^{2}$ openings and $50 \mu \mathrm{m}$ mesh nets. In each haul, samples were obtained from 5 pre-programmed strata from $400 \mathrm{~m}$ depth and up. Samples were split in half on a Folsom plankton splitter and one half was freeze-dried for analysis of $\mathrm{C}$ and $\mathrm{N}$ stable isotopes.

Carbon and nitrogen isotope analyses were performed at the Scottish Crop Research Institute using an automated nitrogen-carbon analyser (ANCA) coupled to a 20/20 isotope ratio mass spectrometer (SerCon). Samples in crimped tin capsules were introduced via a solid autosampler. The elemental analyzer (EA) reactor tubes were comprised of 2 quartz glass tubes filled with chromium(III) oxide and copper oxide held at $1000^{\circ} \mathrm{C}$, and reduced copper held at $620^{\circ} \mathrm{C}$, for combustion and reduction, respectively. A post-reactor gas chromatography (GC) column was kept at $70^{\circ} \mathrm{C}$ for separation of evolved $\mathrm{N}_{2}$ and $\mathrm{CO}_{2}$. The working standard for $\mathrm{N}$ analysis was $1 \mathrm{mg}$ leucine prepared by freeze-drying $50 \mu \mathrm{l}$ of a $20 \mathrm{mg} \mathrm{ml}^{-1}$ stock solution into tin cups, and calibrated against 'Europa flour' and IAEA standards N1 and N2. Only nitrogen isotopes were used in this study and data are reported as $\delta^{15} \mathrm{~N}$ relative to air according to the formula:

$$
\delta^{15} \mathrm{~N}=\left[\left(\mathrm{R}_{\text {sample }} / \mathrm{R}_{\text {standard }}\right)-1\right] \times 1000
$$

where $\mathrm{R}$ is the ratio of the heavy to the light isotope $\left({ }^{15} \mathrm{~N} /{ }^{14} \mathrm{~N}\right)$.

In order to convert the $\delta^{15} \mathrm{~N}$ of the seston from the different strata to a $\delta^{15} \mathrm{~N}$ value for seston in the water column as a whole, the isotope signature for each stratum was multiplied by the weight of the seston in that stratum divided by the total weight of seston in the water column down to $400 \mathrm{~m}$ and the results for all strata summed.

\section{RESULTS}

A thermal frontal system characteristic of the STCZ was encountered between ca. 24.5 and $27^{\circ} \mathrm{N}$ on all 3 transects. Transect 1 supplied the best coverage of the frontal region as well as waters to the north and south of the front and characteristics of that transect are illustrated in Fig. 2a. The region to the north was characterized by considerably colder surface water compared to south of the front, with temperatures at $10 \mathrm{~m}$ depth $<21^{\circ} \mathrm{C}$ (e.g. Stn $17-43$ at $27.66^{\circ} \mathrm{N}$ ). In contrast, the temperatures at $10 \mathrm{~m}$, between ca. 26 to $27.33^{\circ} \mathrm{N}$ (e.g. Stn 17-25 to 17-36), were between 22.9 and $23.3^{\circ} \mathrm{C}$. Relatively small salinity changes were observed in the same area with salinities ranging between 36.70 and 36.78 at $10 \mathrm{~m}$ (i.e. $\mathrm{S}_{\mathrm{P}}$, PSS-78). A clear sub-surface salinity maximum, corresponding to Subtropical Underwater (STUW) was observed south of the front at intermediate depths, i.e. between 100 and 200 m; elevated sub-surface salinities were also noted north of the frontal region (Fig. 2b). Relatively low dissolved oxygen concentrations in the STUW of around $175 \mu \mathrm{mol} \mathrm{kg}{ }^{-1}$ were clearly separated from the more well-ventilated subtropical mode water (STMW, also referred to as 'Eighteen-degree water') observed in the depth range 200 to $400 \mathrm{~m}$ (Fig. 2c).

There are no commonly accepted criteria for identifying the geographic boundaries of a frontal region. For our analyses, we chose to define the frontal region as being where outcropping isopycnals had a density range $\left(\sigma_{t}\right)$ of 24.5 to $25.5 \mathrm{~kg} \mathrm{~m}^{-3}$. Here, the water characteristics were relatively constant and characterized by surface temperatures between 22.3 and $25^{\circ} \mathrm{C}$ (at a depth of $10 \mathrm{~m}$ ) and salinities above 34.48 (Fig. 3). Stations to the north of the frontal region were significantly colder and waters south of the fronts were significantly warmer and less saline. Temperature and salinity were therefore relatively similar in the frontal region along the 3 transects. Where there is good data coverage for both frontal and non-frontal stations, all of the collected data are presented here for purposes of comparison. However, the focus of the analyses is on the frontal region itself, and trying to identify and understand heterogeneity in both water column characteristics and biological activity within this region.

In the deep waters encountered in the frontal region, i.e. below ca. 200 m, the STMW mass was relatively well-ventilated with apparent oxygen utilisa- 

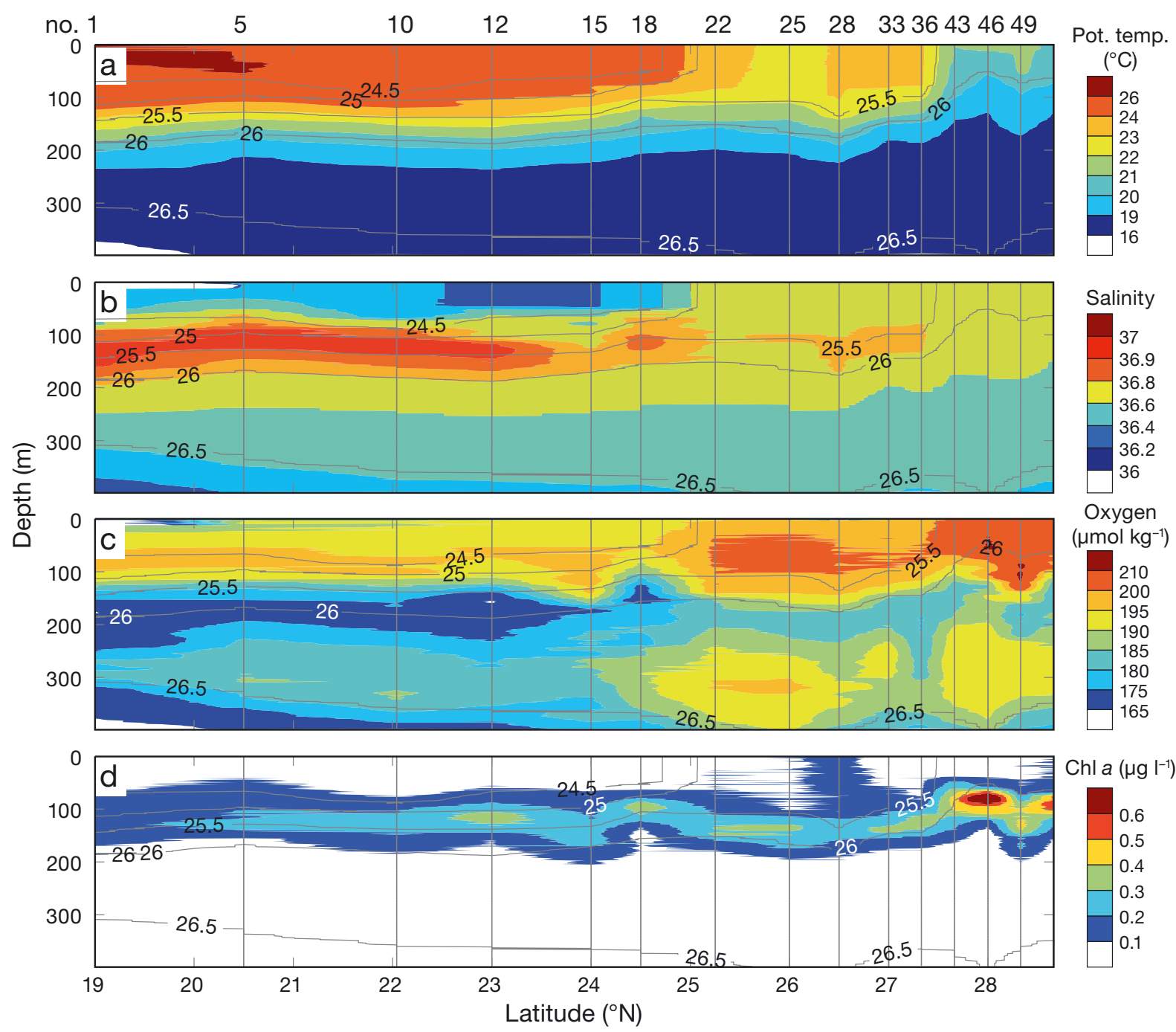

Fig. 2. Observations of (a) potential temperature $\left({ }^{\circ} \mathrm{C}\right)$, (b) salinity, (c) oxygen $\left(\mu m o l \mathrm{~kg}^{-1}\right.$ ) and (d) chlorophyll a $\left(\mu \mathrm{g} \mathrm{l}^{-1}\right)$ derived from fluorescence along Transect 1 at $64^{\circ} \mathrm{W}$. Isopycnals are contoured in intervals of $0.5 \mathrm{~kg} \mathrm{~m}^{-3}$

tion (AOU) values below $50 \mu \mathrm{M}$ (Fig. 4b,d,f). Higher AOU was observed on the more southerly stations along Transect $1\left(64^{\circ} \mathrm{W}\right)$. Transects 2 and 3 only traversed the northern part of the frontal region and thus did not extend into the region where high AOU values in the STMW were recorded on Transect 1. However, in all other respects, the density structure along the 3 transects appears to be comparable.

In our initial analysis of the data, we noted 5 consecutive stations with a high similarity (Jaccard

Fig. 3. Potential temperature $(\theta)$ and salinity (S) of CTD surface measurements along the 3 transects: $64^{\circ} \mathrm{W}(\mathrm{O}), 67^{\circ} \mathrm{W}$ $(\diamond, \diamond)$ and $70^{\circ} \mathrm{W}(\nabla, \nabla)$. Filled symbols show locations with both biology and CTD measurements. Isopycnals $\left(\sigma_{t}\right)$ are shown in intervals of $0.5 \mathrm{~kg} \mathrm{~m}^{-3}$. The frontal region is here defined as stations falling between the isopycnals designated by the bold lines

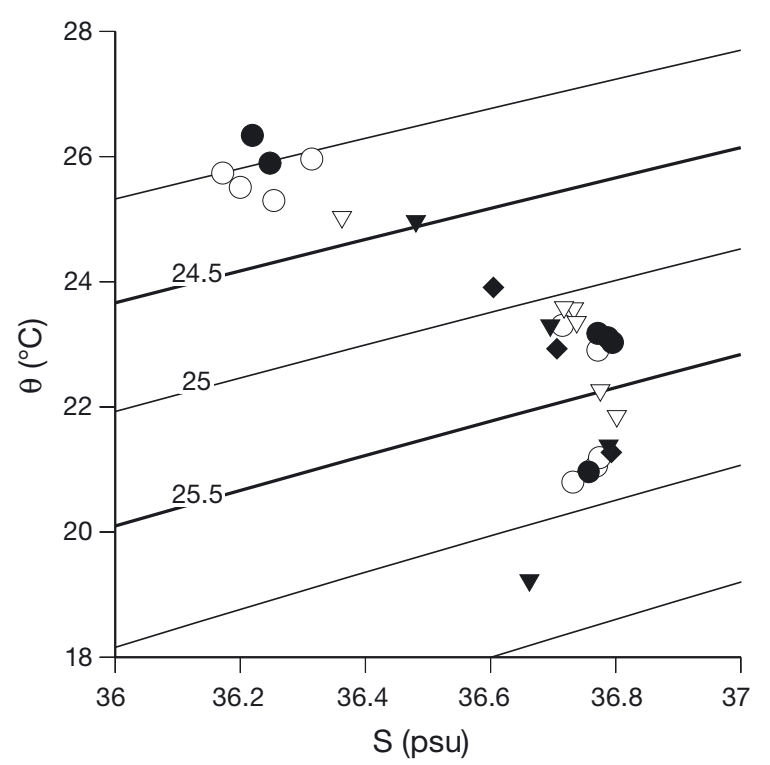



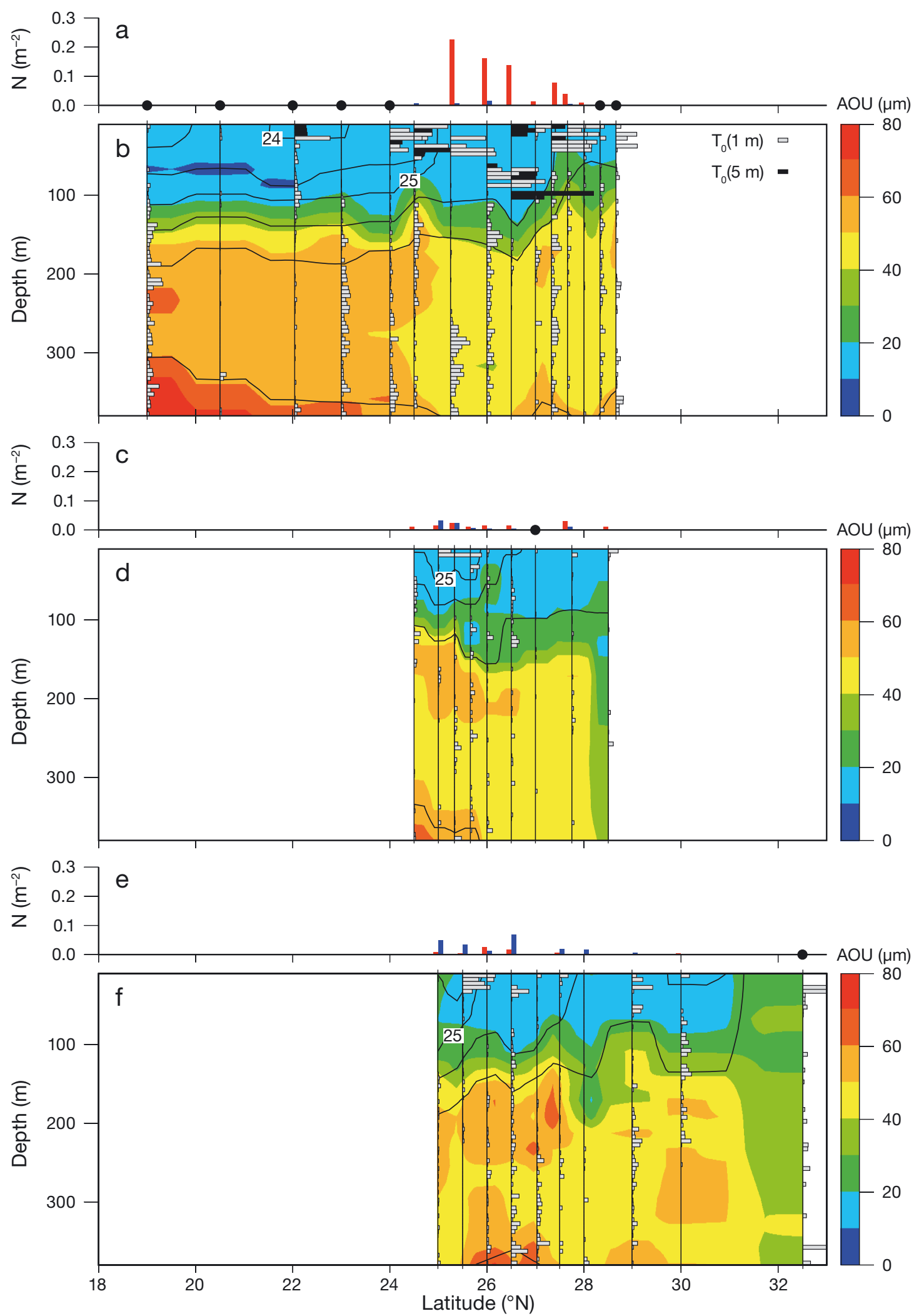

Fig. 4. Apparent oxygen utilization (colors in $\mu \mathrm{M}$ ) and Thorpe displacements $\left(\mathrm{T}_{0}\right)$ binned in $5 \mathrm{~m}$ depth intervals along (b) Transect 1 at $64^{\circ} \mathrm{W}$, (d) Transect 2 at $67^{\circ} \mathrm{W}$ and (f) Transect 3 at $70^{\circ} \mathrm{W}$ (all transects are shown against latitude, i.e. white areas are outside of the transects). Length scale of $\mathrm{T}_{0}$ is shown in upper right corner of panel (b), and colors indicate units of $1 \mathrm{~m}$ (light gray) and $5 \mathrm{~m}$ (black), respectively. Isopycnals $\left(\sigma_{\theta}\right)$ are contoured in intervals of $0.5 \mathrm{~kg} \mathrm{~m}^{-3}$. Abundances of eel-larvae, redrawn from the study of Munk et al. 2010 ( $\mathrm{N}$ is number of larvae $\mathrm{m}^{-2}$ ) in the depth interval between 50 and $200 \mathrm{~m}$ along each transect are shown in (a), (c) and (e). Net samples without eel-larvae are marked with $\bullet$. Two species of eel larvae are shown by red 
Index) between the diatom communities at the surface and the DCM (Fig. 5). These stations coincided with the frontal region along Transect 1 . To test the hypothesis that $J$ might be used as a proxy for mixing in the water column, we compared this index to the temperature difference from $10 \mathrm{~m}$ to the DCM. The 2 parameters were significantly negatively correlated (t-test, $\mathrm{p}<0.05, \mathrm{n}=25$ ), suggesting that the Jaccard Index may be used as a proxy for water column stratification (and therefore mixing) in this region. As it was only in the frontal region of Transect 1 that we noted these relatively high Jaccard indices, we hypothesized that the vertical mixing intensity within the frontal region as a whole might vary and thereby lead to heterogeneity in the conditions for plankton growth and feeding within the region. We therefore turned to other methods to estimate the distribution of vertical mixing within the frontal region.

Thorpe displacements recorded in the frontal region along Transect 1, i.e. the same region that we recorded the highest Jaccard indices, were considerably larger than those recorded on Transects 2 and 3.

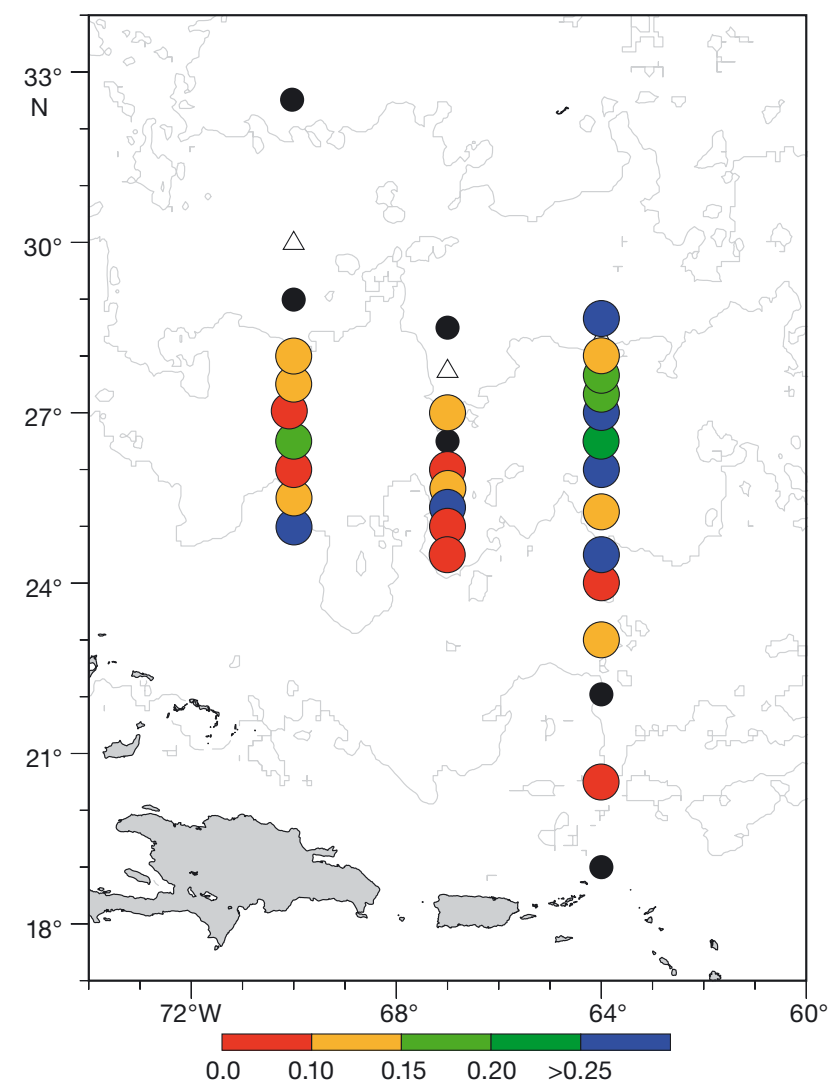

Fig. 5. Jaccard Index for diatoms at the surface $(10 \mathrm{~m})$ versus the deep chlorophyll maximum (DCM). The Jaccard index is shown by colors. Positions of stations without observations of phytoplankton species are indicated together with isolines of sea surface temperature (SST) (symbols and SST as in Fig. 1)
The largest Thorpe displacements along Transect 1 were observed in the surface mixed layer, i.e. the upper $100 \mathrm{~m}$, and also in the depth stratum of 100 to $200 \mathrm{~m}$ in the frontal area (Fig. 4). Eel larvae (redrawn from Munk et al. 2010) were encountered on all 3 transects and only in the frontal region (as defined above), i.e. in the region of the well-ventilated STMW (Fig. 4a,c,e). The largest eel larvae concentrations were observed in the frontal region on Transect 1, where Thorpe displacements also were significantly higher than elsewhere.

The distribution of Thorpe displacements suggests that mixing intensities in the frontal region on Transect 1 were larger than those encountered in the frontal region on the other 2 transects, and is supported by the relatively low Richardson numbers $\left(R i<10^{-2}\right)$ recorded in the frontal region of Transect 1 (Fig. 6). These low values result from weak vertical stratification (i.e. a low Brunt-Väisälä frequency) and relatively large vertical velocity shear below the mixed layer. In the upper $120 \mathrm{~m}$, the locations with low Richardson numbers were in good agreement with areas characterized by large Thorpe displacements (Fig. 4, Table 2). The situation is somewhat different for depths below $100 \mathrm{~m}$. These were, in general, characterized by relatively high Richardson numbers which would indicate the occurrence of less turbulent mixing, while the Thorpe displacements indicated significant mixing deeper in the water column. We note, however, that current velocities below $100 \mathrm{~m}$ were generally $<1 \mathrm{~cm} \mathrm{~s}^{-1}$ and that under these conditions, deep vertical variations in currents become difficult to detect (i.e. a low signal to noise ratio). In contrast to Transect 1 , Transects 2 and 3 were, in general, characterized by relatively large Richardson numbers in the entire water column below $50 \mathrm{~m}$ (Table 2). This distribution of Richardson numbers indicates a much lower influence from turbulent mixing in the upper ocean in the frontal region on these 2 transects compared to that encountered on Transect 1.

Turbulent diffusion coefficients $\left(k_{\mathrm{v}}\right)$ were estimated by applying the KPP parameterisation in the frontal regions of the 3 transects. Low $R i$ values at Transect 1 resulted in large diffusion coefficients of about $10^{-3} \mathrm{~m}^{2}$ $\mathrm{s}^{-1}$, whereas relatively low diffusion coefficients of about $10^{-5} \mathrm{~m}^{2} \mathrm{~s}^{-1}$ were found on Transects 2 and 3 . The corresponding vertical nutrient fluxes (converted into carbon units) were calculated from the vertical nutrient gradients and the diffusion coefficients. The largest vertical diffusion coefficients in the frontal zone were recorded on Transect 1 (Table 2). 


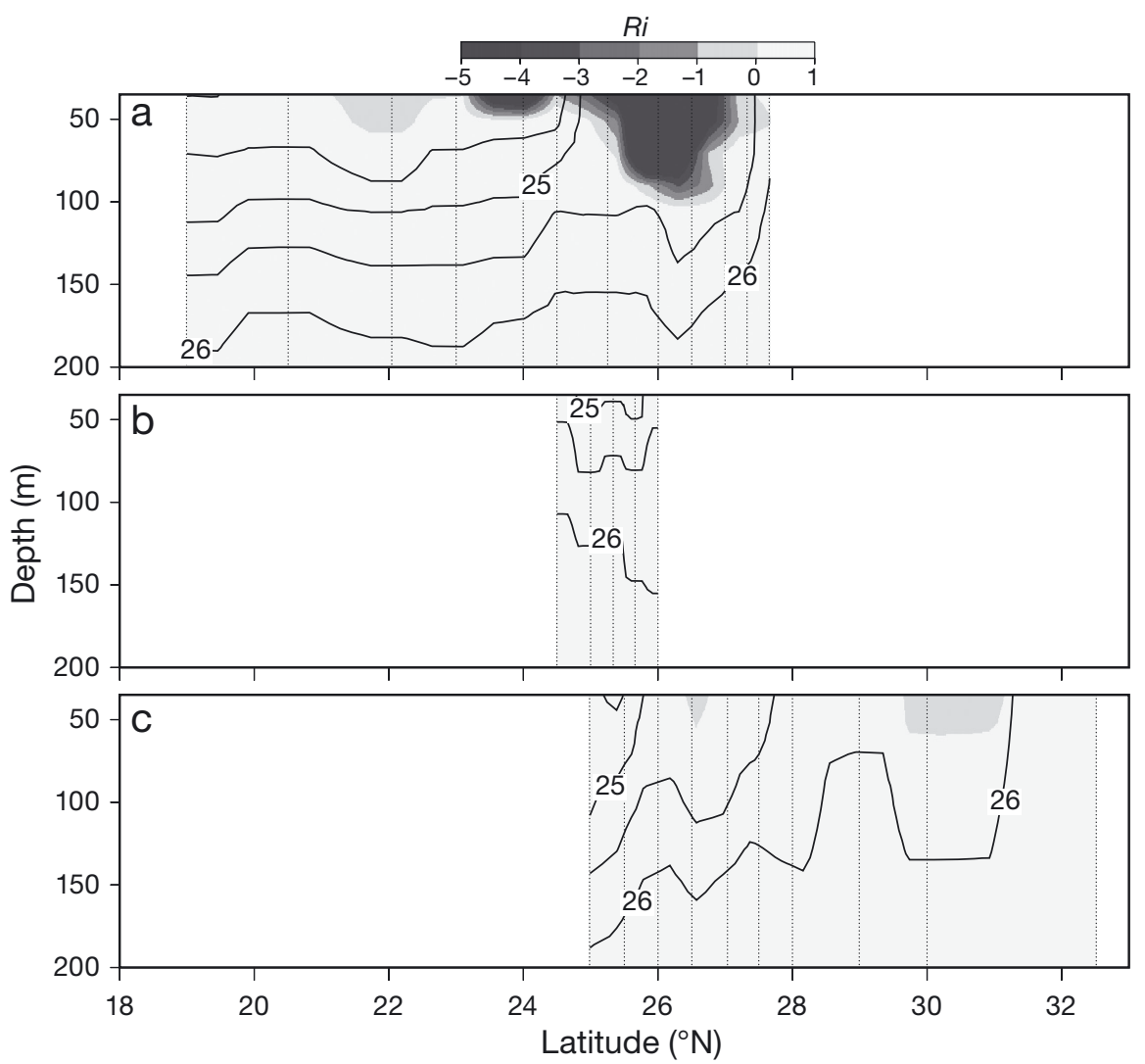

Fig. 6. Distribution of the Richardson number ( $R$ i) along (a) Transect 1 at $64^{\circ} \mathrm{W}$, (b) Transect 2 at $67^{\circ} \mathrm{W}$ and (c) Transect 3 at $70^{\circ} \mathrm{W}$. Isopycnals $\left(\sigma_{\theta}\right)$ are contoured in intervals of $0.5 \mathrm{~kg} \mathrm{~m}^{-3}$. Acoustic Doppler current profiler (ADCP) measurements binned in $16 \mathrm{~m}$ intervals are shown with small dots
At all stations, inorganic nutrients were low in surface waters: nitrate in the upper $200 \mathrm{~m}$ was $\leq 3.64 \mu \mathrm{mol} \mathrm{kg} \mathrm{kg}^{-1}$

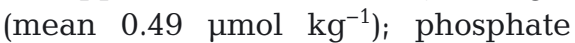
$\leq 0.10 \mu \mathrm{mol} \mathrm{kg}{ }^{-1}$ (mean $0.03 \mu \mathrm{mol} \mathrm{kg}{ }^{-1}$ ) and silicate between 0.45 and $1.22 \mu \mathrm{mol} \mathrm{kg}{ }^{-1}$ (mean $0.70 \mu \mathrm{mol} \mathrm{kg}{ }^{-1}$ ). The nutricline was located at around $200 \mathrm{~m}$ over most of the study area. When the $200 \mathrm{~m}$ sample was excluded, nitrate concentrations in surface waters were $\leq 1.69 \mu \mathrm{mol} \mathrm{kg}{ }^{-1}$ (mean $0.22 \mu \mathrm{mol} \mathrm{kg}^{-1}$ ) and phosphate $\leq 0.08 \mu \mathrm{mol} \mathrm{kg} \mathrm{kg}^{-1}$ (mean 0.03 umol $\mathrm{kg}^{-1}$ ). In the strongly stratified waters farthest south, the low nutrient concentrations extended to even deeper waters, i.e. to between 200 and $400 \mathrm{~m}$, than was the case for the rest of the stations along the transect. The vertical gradients of DIN and dissolved inorganic phosphate (DIP) between the DCM and $200 \mathrm{~m}$ depth varied between $\left(-4.23 \times 10^{-2}\right)-\left(-0.98 \times 10^{-2}\right) \mu \mathrm{M} \mathrm{m}^{-1}$ and $\left(-6.31 \times 10^{-4}\right)-\left(-1.41 \times 10^{-4}\right) \mu \mathrm{M}$ $\mathrm{m}^{-1}$, respectively. The weakest nitrate gradient was observed below the DCM at Stn 28 in accordance with the larger mixing intensity at this station.

Table 2. Density and vertical stratification characteristics in the frontal region of the 3 transects. Density $\left(\sigma_{\theta}\right)$, Brunt-Väisälä frequency $(N)$, Thorpe displacements $\left(L_{T}\right)$ and velocity speed $(V)$ were averaged in the depth interval between 70 and $120 \mathrm{~m}$; the minimum Richardson number $[\min (R i)]$ in this depth interval is also shown. Vertical nutrient gradients of $D I N$ and $D I P$ are determined between the depth of the chlorophyll maximum and $200 \mathrm{~m}$. The average diffusion coefficient $\left(<k_{\mathrm{v}}>\right)$, based on the KPP parameterisation, is applied for estimating the corresponding vertical DIN flux $\left[\mathrm{F}_{\mathrm{N}}(\mathrm{DIN})\right]$ and, via the Redfield ratio, this was converted to carbon units $\left[\mathrm{F}_{\mathrm{C}}(\mathrm{DIN})\right]$

\begin{tabular}{|c|c|c|c|c|c|c|c|c|c|c|}
\hline Station & $\begin{array}{c}\sigma_{\theta} \\
\left(\mathrm{kg} \mathrm{m}^{-3}\right)\end{array}$ & $\begin{array}{c}N 10^{-2} \\
\left(\mathrm{~s}^{-1}\right)\end{array}$ & $\begin{array}{c}L_{T} \\
(\mathrm{~m})\end{array}$ & $\begin{array}{c}V \\
\left(\mathrm{~m} \mathrm{~s}^{-1}\right)\end{array}$ & $\min (R i)$ & $\begin{array}{l}D I N_{z} 10^{-2} \\
\left(\mu \mathrm{M} \mathrm{m}^{-1}\right)\end{array}$ & $\begin{array}{l}D I P_{z} 10^{-4} \\
\left(\mu \mathrm{M} \mathrm{m}^{-1}\right)\end{array}$ & $\begin{array}{c}<k_{\mathrm{v}}>10^{-4} \\
\left(\mathrm{~m}^{2} \mathrm{~s}^{-1}\right)\end{array}$ & $\begin{array}{c}\mathrm{F}_{\mathrm{N}}(\mathrm{DIN}) \\
\left(\mathrm{mg} \mathrm{N} \mathrm{m}^{-2} \mathrm{~d}^{-1}\right)\end{array}$ & $\begin{array}{c}\mathrm{F}_{\mathrm{C}}(\mathrm{DIN}) \\
\left(\mathrm{mg} \mathrm{C} \mathrm{m}^{-2} \mathrm{~d}^{-1}\right)\end{array}$ \\
\hline Interval (m): & $70-120$ & $70-120$ & $70-120$ & $70-120$ & $70-120$ & DCM-200 & DCM-200 & $70-120$ & $\sim \mathrm{DCM}$ & $\sim \mathrm{DCM}$ \\
\hline \multicolumn{11}{|l|}{ Transect 1} \\
\hline $17-22$ & 25.402 & 0.81 & 0.03 & 0.19 & 1.9 & -2.66 & -6.07 & 0.13 & 0.42 & 2.4 \\
\hline $17-25$ & 25.408 & 0.66 & 1.18 & 0.11 & $<10^{-6}$ & - & - & 11.1 & & \\
\hline $17-28$ & 25.308 & 0.36 & 8.87 & 0.12 & $<10^{-6}$ & -0.98 & -4.90 & 10.3 & 12.20 & 69.3 \\
\hline \multicolumn{11}{|l|}{ Transect 2} \\
\hline $17-61$ & 25.988 & 0.59 & 0.17 & - & - & -2.13 & -6.25 & - & & \\
\hline $17-63$ & 25.796 & 0.63 & 0.05 & 0.10 & 1.7 & - & - & 0.14 & & \\
\hline $17-65$ & 25.659 & 0.94 & 0.11 & 0.08 & 8.4 & - & - & 0.11 & & \\
\hline $17-68$ & 25.770 & 1.0 & 0.02 & 0.07 & 21.4 & - & - & 0.10 & & \\
\hline $17-72$ & 25.637 & 1.1 & 0.00 & 0.06 & 13.9 & -4.23 & -3.62 & 0.11 & 0.56 & 3.2 \\
\hline \multicolumn{11}{|l|}{ Transect 3} \\
\hline $17-79$ & 24.934 & 0.77 & 0.00 & 0.09 & 6.6 & -1.49 & -1.41 & 0.12 & 0.22 & 1.2 \\
\hline $17-80$ & 25.201 & 1.1 & 0.03 & 0.06 & 6.3 & - & - & 0.11 & & \\
\hline $17-83$ & 25.553 & 1.0 & 0.04 & 0.11 & 31.6 & - & - & 0.10 & & \\
\hline $17-87$ & 25.341 & 0.90 & 0.16 & 0.21 & 1.3 & - & - & 0.16 & & \\
\hline $17-94$ & 25.450 & 0.84 & 0.02 & 0.10 & 1.1 & -3.90 & -6.31 & 0.22 & 1.04 & 5.9 \\
\hline
\end{tabular}


A distinct sub-surface deep chlorophyll a maximum (DCM) was observed on all transects with typical chl a values between 0.2 and $0.4 \mu \mathrm{g} \mathrm{l}^{-1}$ located at ca. $120 \mathrm{~m}$ and between the 25 to $26 \mathrm{~kg} \mathrm{~m}^{-3}$ isopycnal $\left(\sigma_{\theta}\right)$. The highest chlorophyll concentrations in the DCM were observed north of $27.5^{\circ} \mathrm{N}$ (e.g. Fig. 2d). South of the front and in the frontal region, the DCM was located between 100 and $150 \mathrm{~m}$. Primary production estimates indicated that between 18 and $87 \%$ of the total water column primary production (PP) was generated in these DCM (mean $50 \pm 22 \%$ ). The vertical attenuation coefficient, $k\left(E_{d}=E_{0} \mathrm{e}^{-k d}\right.$, where $E_{d}$ is the irradiance at a given depth $(d)$ and at the surface $\left(E_{0}\right)$, respectively) varied between 0.02 and $0.06 \mathrm{~m}^{-1}$ in the study area. Thus, between about 0.2 and $13 \%$ of surface light could be expected to penetrate to $100 \mathrm{~m}$. At the stations north of the front on all transects, the depth of the DCM decreased but remained below $50 \mathrm{~m}$.

There was considerable variability in the water column particulate primary production (PP) recorded in the study area as a whole (Table 3). This is to be expected given that at least 3 different water regions were being sampled (i.e. the front, and regions both to the north and south). There were too few samples made in total within the frontal region to detect significant differences between the estimates. However, we note that the highest (329 $\mathrm{mg} \mathrm{C} \mathrm{d} \mathrm{d}^{-1}$ ) of the 6 primary production estimates made in the frontal region (i.e. 2 on each transect) was recorded at Stn 17-28 on Transect 1, i.e. the same station where the greatest vertical nutrient flux was estimated.

The variable fluorescence $\left(F_{\mathrm{v}} / F_{\mathrm{m}}\right)$ measurements made at the DCM were significantly higher ( $t$-test; $\mathrm{p}<0.01)$ than the values from all other depths (Table 3). DCM values were relatively high (>0.3) at all stations in the frontal region where data were available. However, only at the frontal stations on Transect 1 did these values (>0.3) extend to shallower depths (i.e. $F_{\mathrm{v}} / F_{\mathrm{m}}$ of 0.39 at $30 \mathrm{~m}$ at Stn 17-22 and 0.34 at $60 \mathrm{~m}$ at Stn 17-28). This suggests that the phytoplankton communities above the DCM were more nutrient replete in the frontal region of Transect 1 than in the frontal region of the other 2 transects.

The structure of the chlorophyll-containing microand nanoplankton community was similar at all stations (Table 4). Flagellates dominated the biomass and dinoflagellates were the second most important group. Together, these 2 groups comprised over $95 \%$ of the biomass at all stations and depths. Mixotrophic dinoflagellates were more abundant than autotrophic both at $10 \mathrm{~m}$ and at the DCM ( $t$-test; $\mathrm{p}<0.01)$. Diatoms contributed from 0.1 to $5 \%$ of the total biomass at all stations and depths. In all, 44 different diatom morphotypes were identified in the study area.
No significant patterns were detected in the distribution of mesozooplankton (calanoid and cyclopoid copepods and their nauplii) in the data set as a whole - either with respect to front/non-frontal stations or the vertical distribution in relation to water column stratification (using the temperature difference between $10 \mathrm{~m}$ and the depth of the DCM as a proxy for stratification). Mesozooplankton data were collected at 11 stations in the frontal region (3 on Transect 1, and 4 on both Transects 2 and 3). No significant differences in the abundance of copepods or their nauplii were found between the frontal region on Transects 1 and 2. However, there were significantly fewer ( $\mathrm{p}<0.01$, Mann-Whitney $U$-test) calanoid and cyclopoid copepods in the frontal region of Transect 3 than on the other 2 transects considered together. Seemingly fewer nauplii were recorded in the frontal region of Transect 3 than on the other 2 transects, although the difference was not significant. Two determinations of total seston in the upper $400 \mathrm{~m}$ were made in the frontal region on both Transects 1 and 3 . These indicated that the seston concentration in the frontal region of Transect 1 was approximately double that on Transect 3 (Table 5).

Stratified sampling of mesozooplankton distribution was made on 7 (5 for nauplii) frontal stations (3 on Transect 1 and 4 on Transect 3). In contrast to the data set as a whole, the vertical distribution of mesozooplankton within the frontal region appeared to be related to water column stratification. A significant correlation $(\mathrm{p}<0.05)$ was found between the Brunt-Väisälä frequency (averaged between 70 and $120 \mathrm{~m}$ ) and the fraction of nauplii biomass beneath $75 \mathrm{~m}$. Another significant correlation $(\mathrm{p}<0.05)$ was found between the Brunt-Väisälä frequency and the fraction of calanoid plus cyclopoid copepods beneath $75 \mathrm{~m}$. The significance of the correlations was tested using Pearson's product moment correlation, and the Shapiro-Wilk test showed that the residuals were normally distributed. Thus, the less stratified (more mixed) the water column was in the 70 to $120 \mathrm{~m}$ depth interval, the more concentrated mesozooplankton and their nauplii were in the deeper part of the water column (i.e. closest to the DCM and nutricline).

The $\delta^{15} \mathrm{~N}$ signature of the seston was determined at 5 stations along Transect 1 . Average water column seston $\delta^{15} \mathrm{~N}$ ranged from 1.97 to $3.64 \%$ along the transect approaching the frontal region from the south and reached $4.46 \%$ in the colder waters north of the frontal region (Stn 17-43). This latitudinal trend for average water column seston $\delta^{15} \mathrm{~N}$ was significant $\left(\mathrm{p}=0.006 ; \mathrm{R}^{2}=0.74\right)$. (Table 6). 
Table 3. Mean and standard deviation (SD) of variable fluorescence $\left(F_{\mathrm{v}} / F_{\mathrm{m}}\right)$ at all sampled depths where valid data were recovered. Data for samples from the DCM are in bold. Three replicate samples (from the same Niskin bottle) were made at each depth and 3 measurements on each sample. Sample positions are given as (a) in the frontal zone, i.e. in the region between the surface outcropping of the 24.5 and $25.5 \mathrm{~kg} \mathrm{~m}^{-3}$ isopycnals $\left(\sigma_{\theta}\right)_{i}$ (b) north of the frontal zone; and (c) south of the frontal zone. For each station, total water column primary

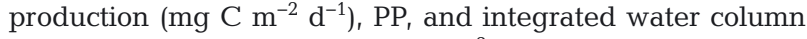
chlorophyll a (chl $a_{i} \mathrm{mg} \mathrm{m}^{-2}$ ) are also given

\section{DISCUSSION}

Most studies attempting to explain the association of particular biological features with frontal regions compare conditions inside the region with those outside. This approach was applied by Andersen et al. (2011) and Riemann et al. (2011) in an unsuccessful effort to find a possible explanation for the observation that eel larvae were only found within the frontal region of the STCZ in the Sargasso Sea (Munk et al. 2010). Andersen et al. (2011) did find an increased biomass of some zooplankton groups/species in the frontal region compared to the non-frontal stations, but neither study found evidence for increased primary or secondary production at the frontal compared to the non-frontal stations. Using data collected on the same cruise as the 3 earlier studies (Munk et al. 2010, Andersen et al. 2011, Riemann et al. 2011), we adopted a different strategy and examined the frontal region itself for evidence of heterogeneity in physical and chemical conditions that might locally impact biological production. Our results suggest that vertical mixing conditions and consequentially the magnitude of vertical nutrient fluxes may vary considerably between stations in the frontal region. Therefore, local stimulation of the plankton food web may occur at the sites within the frontal region where vertical nutrient fluxes are greatest. Thus, we suggest that the planktonic food web may be stimulated by the introduction of nutrients at specific sites in the frontal regions rather than in the frontal zone as a whole.

The location of the front encountered on this study is in accordance with previous satellite derived observations of fronts in the STCZ (Ullman et al. 2007). The salinity maximum we observed (south of the frontal zone between 40 and $30^{\circ} \mathrm{W}$ ) may be associated with the Subtropical Underwater mass (STUW), which is formed by subduction in a large area across the central subtropical gyres (between $20^{\circ}$ and $30^{\circ} \mathrm{N}$; $\mathrm{O}^{\prime}$ Connor et al. 2005). O'Connor et al. (2005) found

\begin{tabular}{|c|c|c|c|c|}
\hline Station & $\begin{array}{l}\text { Depth } \\
\text { (m) }\end{array}$ & $F_{\mathrm{v}} / F_{\mathrm{m}} \pm \mathrm{SD}$ & 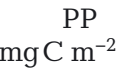 & $\begin{array}{c}\text { Int. chl } a \\
\left(\mathrm{mg} \mathrm{chl} \mathrm{m}^{-2}\right)\end{array}$ \\
\hline \multicolumn{5}{|c|}{ (a) Frontal zone stations } \\
\hline \multicolumn{5}{|c|}{ Transect 1} \\
\hline \multirow[t]{4}{*}{$17-22$} & 10 & $0.25 \pm 0.05$ & 130 & 24 \\
\hline & 30 & $0.39 \pm 0.02$ & & \\
\hline & 140 (DCM) & $0.48 \pm 0.01$ & & \\
\hline & 200 & $0.19 \pm 0.01$ & & \\
\hline \multirow[t]{4}{*}{$17-28$} & 10 & $0.28 \pm 0.02$ & 329 & 23 \\
\hline & 60 & $0.34 \pm 0.01$ & & \\
\hline & 00 (DCM) & $0.31 \pm 0.01$ & & \\
\hline & 200 & $0.12 \pm 0.01$ & & \\
\hline \multicolumn{5}{|c|}{ Transect 2} \\
\hline \multirow[t]{4}{*}{$17-61$} & 10 & $0.14 \pm 0.01$ & 45 & 29 \\
\hline & 60 & $0.15 \pm 0.01$ & & \\
\hline & 80 & $0.24 \pm 0.01$ & & \\
\hline & 200 & $0.07 \pm 0.03$ & & \\
\hline \multirow[t]{4}{*}{$17-72$} & 10 & $0.19 \pm 0.01$ & 184 & 27 \\
\hline & 60 & $0.28 \pm 0.002$ & & \\
\hline & 30 (DCM) & $0.31 \pm 0.01$ & & \\
\hline & 200 & $0.050 \pm 0.03$ & & \\
\hline \multicolumn{5}{|c|}{ Transect 3} \\
\hline \multirow[t]{4}{*}{$17-79$} & 10 & $0.14 \pm 0.10$ & 244 & 22 \\
\hline & 60 & $0.30 \pm 0.02$ & & \\
\hline & 25 (DCM) & $0.39 \pm 0.17$ & & \\
\hline & 200 & $0.16 \pm 0.01$ & & \\
\hline \multirow[t]{4}{*}{$17-83$} & 10 & $0.035 \pm 0.01$ & & \\
\hline & 60 & $0.087 \pm 0.01$ & & \\
\hline & 25 (DCM) & $0.36 \pm 0.02$ & & \\
\hline & 150 & $0.42 \pm 0.01$ & & \\
\hline \multirow[t]{3}{*}{$17-94$} & 10 & $0.24 \pm 0.001$ & 116 & 22 \\
\hline & 60 & $0.25 \pm 0.01$ & & \\
\hline & 200 & $0.12 \pm 0.07$ & & \\
\hline \multicolumn{5}{|c|}{ (b) Stations north of frontal zone } \\
\hline \multicolumn{5}{|c|}{ Transect 1} \\
\hline \multirow[t]{5}{*}{$17-43$} & 10 & $0.20 \pm 0.03$ & 276 & 33 \\
\hline & 60 & $0.26 \pm 0.01$ & & \\
\hline & 80 & $0.15 \pm 0.01$ & & \\
\hline & 100 & $0.15 \pm 0.01$ & & \\
\hline & 20 (DCM) & $0.13 \pm 0.01$ & & \\
\hline \multicolumn{5}{|c|}{ Transect 2} \\
\hline \multirow[t]{5}{*}{$17-55$} & 10 & $0.26 \pm 0.03$ & 131 & 27 \\
\hline & 60 & $0.37 \pm 0.01$ & & \\
\hline & 80 & $0.42 \pm 0.01$ & & \\
\hline & 100 (DCM) & $0.44 \pm 0.01$ & & \\
\hline & 170 & $0.31 \pm 0.02$ & & \\
\hline Transe & ct 3 & & & \\
\hline $17-103$ & 10 & $0.27 \pm 0.001$ & 470 & 26 \\
\hline & 60 & $0.30 \pm 0.01$ & & \\
\hline & 83 & $0.35 \pm 0.04$ & & \\
\hline & 200 & $0.14 \pm 0.05$ & & \\
\hline (c) Stat & ions south o & of frontal zone & & \\
\hline Transe & ct 1 & & & \\
\hline $17-1$ & 10 & $0.21 \pm 0.05$ & 322 & 21 \\
\hline & 30 & $0.22 \pm 0.05$ & & \\
\hline & 60 & $0.21 \pm 0.01$ & & \\
\hline $17-10$ & 10 & $0.24 \pm 0.05$ & 197 & 21 \\
\hline & 60 & $0.26 \pm 0.04$ & & \\
\hline & 20 (DCM) & $0.23 \pm 0.01$ & & \\
\hline & 200 & $0.10 \pm 0.003$ & & \\
\hline
\end{tabular}


Table 4. Biomass $\left(\mu \mathrm{g} \mathrm{C}^{-1}\right.$ ) of chlorophyll-containing protists larger than approximately $2 \mu \mathrm{m}$. n: number of stations; Surface: 10 m samples; DCM: deep chlorophyll maximum; dino.: dinoflagellates

\begin{tabular}{|c|c|c|c|c|c|c|c|c|}
\hline & & $\begin{array}{c}\text { Autotrophic } \\
\text { dino. }\end{array}$ & $\begin{array}{l}\text { Mixotrophic } \\
\text { dino. }\end{array}$ & Diatoms & $\begin{array}{c}\text { Trichodesmium } \\
\text { rubrum }\end{array}$ & Mesodinium & Flagellates & $\begin{array}{l}\text { Biomass } \\
\text { totals }\end{array}$ \\
\hline \multicolumn{9}{|c|}{ Transect 1} \\
\hline North & $\begin{array}{l}\text { Surface }(\mathrm{n}=6) \\
\operatorname{DCM}(\mathrm{n}=5)\end{array}$ & $\begin{array}{l}0.30 \pm 0.07 \\
0.16 \pm 0.07\end{array}$ & $\begin{array}{l}1.01 \pm 0.31 \\
1.45 \pm 0.54\end{array}$ & $\begin{array}{l}0.03 \pm 0.03 \\
0.10 \pm 0.06\end{array}$ & $\begin{array}{l}0.00 \pm 0.00 \\
0.00 \pm 0.00\end{array}$ & $\begin{array}{l}0.06 \pm 0.06 \\
0.01 \pm 0.03\end{array}$ & $\begin{array}{l}4.13 \pm 0.95 \\
6.30 \pm 2.37\end{array}$ & $\begin{array}{l}5.54 \pm 1.12 \\
8.02 \pm 2.62\end{array}$ \\
\hline Front & $\begin{array}{l}\text { Surface }(\mathrm{n}=3) \\
\operatorname{DCM}(\mathrm{n}=3)\end{array}$ & $\begin{array}{l}0.29 \pm 0.25 \\
0.11 \pm 0.06\end{array}$ & $\begin{array}{l}0.95 \pm 0.06 \\
1.48 \pm 0.35\end{array}$ & $\begin{array}{l}0.04 \pm 0.05 \\
0.05 \pm 0.05\end{array}$ & $\begin{array}{l}0.00 \pm 0.00 \\
0.00 \pm 0.00\end{array}$ & $\begin{array}{l}0.00 \pm 0.00 \\
0.00 \pm 0.00\end{array}$ & $\begin{array}{l}6.25 \pm 1.24 \\
2.93 \pm 0.87\end{array}$ & $\begin{array}{l}7.52 \pm 1.50 \\
4.58 \pm 0.59\end{array}$ \\
\hline South & $\begin{array}{l}\text { Surface }(\mathrm{n}=5) \\
\operatorname{DCM}(\mathrm{n}=4)\end{array}$ & $\begin{array}{l}0.25 \pm 0.14 \\
0.12 \pm 0.07\end{array}$ & $\begin{array}{l}0.76 \pm 0.32 \\
1.03 \pm 0.25\end{array}$ & $\begin{array}{l}0.06 \pm 0.03 \\
0.05 \pm 0.01\end{array}$ & $\begin{array}{l}0.07 \pm 0.10 \\
0.10 \pm 0.19\end{array}$ & $\begin{array}{l}0.00 \pm 0.00 \\
0.00 \pm 0.00\end{array}$ & $\begin{array}{l}5.49 \pm 1.57 \\
3.10 \pm 1.52\end{array}$ & $\begin{array}{l}6.63 \pm 2.00 \\
4.40 \pm 1.63\end{array}$ \\
\hline \multicolumn{9}{|c|}{ Transect 2} \\
\hline North & $\begin{array}{l}\text { Surface }(\mathrm{n}=3) \\
\operatorname{DCM}(\mathrm{n}=1)\end{array}$ & $\begin{array}{c}0.22 \pm 0.09 \\
0.08\end{array}$ & $\begin{array}{c}0.80 \pm 0.27 \\
1.13\end{array}$ & $\begin{array}{c}0.02 \pm 0.02 \\
0.34\end{array}$ & $\begin{array}{c}0.00 \pm 0.00 \\
0.00\end{array}$ & $\begin{array}{c}0.02 \pm 0.02 \\
0.00\end{array}$ & $\begin{array}{c}4.87 \pm 0.90 \\
4.72\end{array}$ & $\begin{array}{c}5.93 \pm 1.04 \\
6.27\end{array}$ \\
\hline Front & $\begin{array}{l}\text { Surface }(\mathrm{n}=5) \\
\operatorname{DCM}(\mathrm{n}=4)\end{array}$ & $\begin{array}{l}0.21 \pm 0.08 \\
0.16 \pm 0.03\end{array}$ & $\begin{array}{l}0.84 \pm 0.36 \\
1.32 \pm 1.02\end{array}$ & $\begin{array}{l}0.06 \pm 0.01 \\
0.03 \pm 0.08\end{array}$ & $\begin{array}{l}0.33 \pm 0.00 \\
0.00 \pm 0.00\end{array}$ & $\begin{array}{l}0.00 \pm 0.02 \\
0.02 \pm 0.00\end{array}$ & $\begin{array}{l}4.67 \pm 1.24 \\
4.30 \pm 0.59\end{array}$ & $\begin{array}{l}6.11 \pm 1.40 \\
5.84 \pm 1.72\end{array}$ \\
\hline South & $\begin{array}{l}\text { Surface }(n=1) \\
\operatorname{DCM}(n=1)\end{array}$ & $\begin{array}{l}0.31 \\
0.09\end{array}$ & $\begin{array}{l}1.14 \\
1.30\end{array}$ & $\begin{array}{l}0.04 \\
0.04\end{array}$ & $\begin{array}{l}0.00 \\
0.00\end{array}$ & $\begin{array}{l}0.01 \\
0.00\end{array}$ & $\begin{array}{l}5.47 \\
4.36\end{array}$ & $\begin{array}{l}6.96 \\
5.79\end{array}$ \\
\hline \multicolumn{9}{|c|}{ Transect 3} \\
\hline North & $\begin{array}{l}\text { Surface }(\mathrm{n}=5) \\
\operatorname{DCM}(\mathrm{n}=2)\end{array}$ & $\begin{array}{l}0.22 \pm 0.15 \\
0.17 \pm 0.06\end{array}$ & $\begin{array}{l}1.18 \pm 0.64 \\
1.12 \pm 0.05\end{array}$ & $\begin{array}{l}0.05 \pm 0.03 \\
0.07 \pm 0.00\end{array}$ & $\begin{array}{l}0.00 \pm 0.00 \\
0.00 \pm 0.00\end{array}$ & $\begin{array}{l}0.06 \pm 0.07 \\
0.00 \pm 0.00\end{array}$ & $\begin{array}{l}5.96 \pm 5.49 \\
2.98 \pm 0.82\end{array}$ & $\begin{array}{l}7.48 \pm 6.02 \\
4.34 \pm 0.93\end{array}$ \\
\hline Front & $\begin{array}{l}\text { Surface }(\mathrm{n}=5) \\
\operatorname{DCM}(\mathrm{n}=5)\end{array}$ & $\begin{array}{l}0.20 \pm 0.08 \\
0.11 \pm 0.06\end{array}$ & $\begin{array}{l}0.83 \pm 0.19 \\
0.95 \pm 0.43\end{array}$ & $\begin{array}{l}0.04 \pm 0.01 \\
0.08 \pm 0.02\end{array}$ & $\begin{array}{l}0.00 \pm 0.00 \\
0.00 \pm 0.00\end{array}$ & $\begin{array}{l}0.00 \pm 0.00 \\
0.04 \pm 0.09\end{array}$ & $\begin{array}{l}3.40 \pm 2.32 \\
2.46 \pm 1.34\end{array}$ & $\begin{array}{l}4.46 \pm 2.41 \\
3.63 \pm 1.18\end{array}$ \\
\hline South & $\begin{array}{l}\text { Surface } \\
\text { DCM }\end{array}$ & - & - & - & - & - & - & - \\
\hline
\end{tabular}

Table 5. Total seston $\left(\mathrm{mg} \mathrm{m}^{-2}\right)$ from 0 to $400 \mathrm{~m}$ at stations in the frontal region on Transects 1 and 3

\begin{tabular}{|lcc|}
\hline & Station & $\begin{array}{c}\text { Integrated seston } \\
(0-400 \mathrm{~m})\left(\mathrm{mg} \mathrm{m}^{-2}\right)\end{array}$ \\
\hline Transect 1 & $17-22$ & 1627 \\
& $17-28$ & 1318 \\
Transect 3 & $17-80$ & 610 \\
& $17-94$ & 844 \\
\hline
\end{tabular}

Table 6. Stable isotope abundance $\left(\delta^{15} \mathrm{~N}, \%\right)$ in particulate matter (seston) obtained in vertical hauls of a Multinet (50 $\mu \mathrm{m}$ mesh) along Transect 1 at $64^{\circ} \mathrm{W}$

\begin{tabular}{|lccccc|}
\hline \multirow{2}{*}{ Station } & \multicolumn{5}{c|}{ Depth interval $(\mathrm{m})$} \\
\cline { 2 - 6 } & $0-50$ & $50-100$ & $100-200$ & $200-300$ & $300-400$ \\
\hline $17-1$ & 0.58 & 1.44 & 2.65 & 4.13 & 4.57 \\
$17-10$ & 0.87 & 1.74 & 2.35 & 3.18 & 3.88 \\
$17-22$ & 1.26 & 1.94 & 3.07 & 5.04 & 5.50 \\
$17-28$ & 0.60 & 1.84 & 2.43 & 4.56 & 5.34 \\
$17-43$ & 2.34 & 3.30 & 4.14 & 5.01 & 5.18 \\
\hline
\end{tabular}

that the spreading of the STUW in the area occurs at density $\left(\sigma_{\theta}\right)$ levels ranging between 25.6 and $26.3 \mathrm{~kg}$ $\mathrm{m}^{-3}$. This is in accordance with the observed subsurface salinity maximum, and that the average age of the subducted STUW, estimated from CFC-tracer distributions, is 1 to $5 \mathrm{yr}$. The higher oxygen concentrations recorded in the STMW (Fig. 2c) are consistent with previous reports that the STMW is, in general, more ventilated than STUW in the area. For example, seen from meridional sections of the CFC12 tracer in the area, high CFC-12 is observed below the sub-surface salinity maximum of STUW (Joyce et al. 2001).

\section{Evidence for vertical mixing}

Several lines of evidence presented here suggest that vertical mixing was greatest in the frontal region of Transect 1, where Munk et al. (2010) recorded the highest concentrations of eel larvae. Firstly, a large patch where relatively high similarities (Jaccard Index; Fig. 5) in the diatom communities at $10 \mathrm{~m}$ and the DCM were found here. The significant relation- 
ship we found between the Jaccard Index and the difference in temperature between $10 \mathrm{~m}$ and at the DCM suggests that this index may be a reasonable proxy for mixing in this region.

The hydrographic data collected were not of sufficient spatial and temporal resolution to directly observe individual mesoscale eddies. However, we examined data from each CTD station for evidence of vertical mixing at that specific geographic location. Relatively high vertical mixing intensities at intermediate depth levels down to $200 \mathrm{~m}$, in particular at Stn 17-25, were derived from Thorpe displacements in the frontal zone of Transect 1 (Fig. 4). These were considerably higher than the Thorpe displacements calculated for frontal stations on the other 2 transects. Estimates of turbulent vertical diffusion coefficients from Thorpe displacements have been shown to provide estimates of mixing intensities in accordance with mixing intensities derived from other methods (Cisewski et al. 2005), although they are associated with relatively large uncertainties when based on few vertical CTD profiles - as is the case in this study where we only have simultaneous measurements from 2 independent CT sensors.

A vertical diffusion coefficient $\left(k_{\mathrm{v}}\right)$ can be estimated from the Thorpe displacements as: $k_{\mathrm{v}}=\eta L_{T}^{2} N$, where $\eta \sim 0.2$ is a mixing efficiency (Cisewski et al. 2005). Thus, mixing intensity depends strongly on the Thorpe displacements. From the depth-averaged values above the DCM (70 to $120 \mathrm{~m}$ ) of $L_{T}$ and $N$ across the 3 frontal zones, it can be seen that vertical mixing intensities are at least an order of magnitude larger on Transect 1 than on the other 2 transects (Table 2). This conclusion (significantly larger mixing intensities occurring on Transect 1) is supported by the distribution of the minimum Richardson number between 70 and $120 \mathrm{~m}$ depth (a minimum value of $R i$, rather than a vertical average, is more representative for the presence of turbulence in a given depth layer). In general, low $R i$ values (i.e. $R i<0.25)$ indicate areas where the vertical velocity shear is expected to contribute significantly to turbulent mixing. The lowest $R i$ values in this intermediate depth interval were found at Stn 25 and 28 on Transect 1 and these 2 stations were also characterized by the largest Thorpe displacements, indicating substantial vertical mixing here compared to the other stations in the area.

\section{Vertical nutrient fluxes in the frontal region}

In general, nutrient fluxes (F(DIN) and $F(D I P))$ from vertical turbulent mixing can be calculated as:
$\mathrm{F}(\mathrm{DIN})=-k_{\mathrm{v}} D I N_{z}$ (and similarly for $\mathrm{F}(\mathrm{DIP})$ ). Thus, while the deep vertical gradient of DIN between the DCM and $200 \mathrm{~m}$ is slightly smaller at Transect 1 when averaged over the frontal region than on the other 2 transects, the total nutrient flux is predicted to be an order of magnitude larger in the frontal region on Transect 1 compared to the other 2 transects due to the higher mixing intensities (Table 2).

By applying the estimated turbulent diffusion coefficients from the long-term averaged $(1 \mathrm{~h})$ velocity shears, the mixing intensity between 70 and $120 \mathrm{~m}$ depth in the frontal region at Transect 1 was estimated to be 2 orders of magnitude higher than corresponding values from the 2 other transects. When combining these estimates with vertical nutrient gradients below the DCM, the averaged nutrient flux corresponded to $36 \mathrm{mg} \mathrm{C} \mathrm{m}^{-2} \mathrm{~d}^{-1}$ from the 2 stations in the frontal region of Transect 1 (Table 2). Thus, a much higher fraction of PP could be explained by vertical mixing of nutrients here and new production (sensu Dugdale \& Goering 1967) than at other stations in the frontal region. Comparison between the vertical gradients of DIN and DIP indicates that excess nitrate for new production, i.e. $D I N_{\mathrm{z}} / D I P_{\mathrm{z}}>$ 16 , was being transported by vertical mixing to the euphotic zone in the frontal zone of Transect 1.

Eddy-induced mixing in the subtropical gyre has earlier been suggested to play an important role for new production (NP). By forcing a conceptual model of eddy-induced nutrient mixing with satellite observations of the sea surface variability, McGillicuddy et al. (1998) concluded that mesoscale eddy activity had a major impact on the nutrient balance and could explain a significant part (up to $40 \%$ ) of the $\mathrm{N}$ requirement for sustaining the annual NP in the Sargasso Sea. These findings were supported by eddy-permitting high-resolution modeling where it was shown that eddy-induced mixing was an important source of nutrients in the upper ocean (accounting for about $30 \%$ of NP) in the sub- and mid-latitude North Atlantic (Oschlies \& Garçon 1998). A study of the distribution of phytoplankton, in particular the diazotrophic Trichodesmium spp., in a comparable frontal region in the central north Pacific $\left(26^{\circ} \mathrm{N}\right)$, showed that sub-mesoscale and mesoscale $(\sim 50 \mathrm{~km})$ dynamics could explain carbon export and particle accumulation in the upper ocean-although the specific eddy-dynamical processes supporting the nutrient transport remain unresolved (Guidi et al. 2012).

In the study reported here, the similarity of the plankton populations at $10 \mathrm{~m}$ and the DCM, the calculated Thorpe displacements and the mixing intensities inferred from the vertical current shear all sup- 
port the hypothesis that vertical mixing can play a significant role for sustaining the PP in the frontal zone along Transect 1, where the abundance of eel larvae was greatest. We note, however, that horizontal mixing associated with small-scale frontal dynamics may also be important for mixing and transport in the region. In a study of the North Pacific STFZ, it was shown that interleaving across a frontal zone was very intense within a distance of about $5 \mathrm{~km}$ from the front (Shcherbina et al. 2009). Such smallscale features were not resolved by the station spacing in this study, but such mixing processes may further enhance vertical nutrient fluxes.

Relatively small Thorpe displacements at intermediate depths were, in general, recorded south of the frontal zone. The southernmost station (Stn 17-1; Fig. 4) was characterized by a relatively large mixing intensity and this may be related to the dynamic region associated with the Antilles Current (Lee et al. 1996). Relatively modest mixing intensity was recorded north of the frontal zone, except for Stn 17-36 (located just north of the frontal zone defined here) where high mixing was observed.

\section{Biological activity in frontal regions of elevated vertical nutrient flux}

Unfortunately, we collected inadequate sample sizes of biological variables to determine statistically significant differences in plankton production characteristics among frontal stations. However, several lines of evidence suggest heterogeneity in the plankton production processes within the frontal region, and that the elevated vertical nutrient fluxes implied in the frontal region on Transect 1 influence plankton productivity. These arguments include:

(1) The highest primary production estimate recorded in the frontal zone was found at Stn 17-28, i.e. the same station where maximum vertical nutrient flux is implied (Table 2).

(2) Relatively high values of variable fluorescence, $F_{\mathrm{v}} / F_{\mathrm{m}}$, (which is considered to be an indicator of the potential for electron transport in PSII) recorded by Fast Repetition Rate Fluorometry were found at the DCM over the entire study area. While several factors can influence fluorescence kinetics, it is generally assumed that for dark adapted cells, $F_{\mathrm{v}} / F_{\mathrm{m}}$ is an indicator of nutrient status (see review by Beardall et al. 2001). This suggests that phytoplankton in the DCM are generally more nutrient replete than those higher in the water column, and thus that the phytoplankton in the DCM are fuelled by nutrient sources not available to phytoplankton higher in the water column. The only obvious potential nutrient source that would not also be available for phytoplankton higher in the water column would be nutrients from the deep water below. The fact that the relatively high $F_{\mathrm{v}} / F_{\mathrm{m}}$ values recorded at the 2 frontal stations on Transect 1 extended to shallower depths (Table 3) than on any of the frontal stations on Transects 2 and 3 also suggests that the phytoplankton above the DCM in the frontal region of this transect are benefiting from a sub-surface nutrient source. This result also lends support to the hypothesis that greater vertical mixing of nutrients is occurring in the frontal region of Transect 1 than on the 2 other transects. We acknowledge that one of the factors that can influence $F_{\mathrm{v}} / F_{\mathrm{m}}$ in addition to nutrient status is species composition (Suggett et al. 2009). However, the structure of the chlorophyll-containing plankton community was very similar over the entire study area (Table 4). Although we only present data here for the chlorophyll-containing nano- and microplankton (i.e. those plankton that can be observed in the light microscope and > ca. $2 \mu \mathrm{m}$ ), Riemann et al. (2011) presented flowcytometer data describing the distribution of picoplankton on the same stations. They found Prochlorococcus to dominate the picoplankton biomass and to be especially dominant in the DCM. Synecococcus spp. were also present but generally more abundant higher in the water column. They found no significant horizontal patterns in the abundance of picoplankton or the distributions of these groups. They estimated the biomasses of the picoplankton and what they called 'larger algae' (i.e. those we consider here) to be on the same order of magnitude at most stations. Thus, changes in community composition would seem unlikely to be responsible for the differences in $F_{\mathrm{v}} / F_{\mathrm{m}}$ we report here.

(3) The abundance of calanoid and cyclopoid copepods was also significantly lower on Transect 3 than on the other 2 transects combined. Thus, while the seston and mesozooplankton data do not specifically identify Transect 1 as having more secondary production than the 2 other transects, they do indicate that there are significant differences in production patterns within the frontal region. Thus, this result also supports our overall hypothesis of heterogeneity in the plankton food web within the frontal region. One can imagine that vertical mixing of nutrients may be an ephemeral occurrence in this region. As a response in secondary production to vertical nutrient mixing must operate through the response of phytoplankton to the nutrient influx, a time lag is to be expected in the secondary production response in 
relation to the timing of the nutrient influx event. Thus, our inability to distinguish differences in the abundance of calanoid and cyclopoid copepods between Transects 1 and 2 may be related to the previous history of flux events and not the fluxes estimated at the time of our sampling.

(4) Possible support for the hypothesis that the distribution of mesozooplankton may be related to mixing activity is found in the relationship between the vertical distribution of mesozooplankton and the Brünt-Väisälä frequency. The observation that mesozooplankton appear to be more concentrated below $75 \mathrm{~m}$ at stations in the frontal region where there is evidence of mixing may indicate that zooplankton are actively aggregating at this location.

(5) There were very few determinations of total seston, but the 2 taken in the frontal region of Transect 1 compared to the 2 taken in the frontal region of Transect 3 suggest that total seston was approximately twice as high in the frontal region of Transect 1 than on Transect 3 (Table 5).

(6) Finally, the $\delta^{15} \mathrm{~N}$ distributions associated with seston along Transect 1 support the hypothesis that there may be increased vertical mixing of nutrients into the frontal region compared to the waters to the south. Atmospheric nitrogen has, by definition, a $\delta^{15} \mathrm{~N}$ of 0 , while that of deep nitrate is ca. 5 . Thus, the relative contribution of these sources of nitrogen is reflected in the isotope signature of food web components (Montoya et al. 2002). Although absolute values will be affected by trophic enrichment, a higher $\delta^{15} \mathrm{~N}$ will generally indicate a lesser importance of atmospheric nitrogen in fuelling the planktonic food web. Thus, the higher values of $\delta^{15} \mathrm{~N}$ in seston recorded at frontal stations on Transect 1 compared to the more southerly stations on this transect again suggest vertical mixing of nutrients to be occurring here (Table 6).

\section{Phytoplankton community composition}

A striking feature in the plankton community data is the dominance of mixotrophic dinoflagellates among the larger organisms present (Table 4). This is the case at $10 \mathrm{~m}$, but even more so at the DCM. Collos et al. (2013) have recently reported on a mixotrophic dinoflagellate that, under certain grazing conditions, can base over $50 \%$ of its growth (measured as carbon accumulation) on non-autotrophic sources. Given the importance of mixotrophic dinoflagellates in the Sargasso Sea plankton ecosystem, it seems unlikely that carbon accumulation at the base of the food web here is completely reliant on autotrophic processes. Thus, traditional ${ }^{14} \mathrm{C}$ estimates of primary production may potentially seriously underestimate the actual carbon available to the plankton food web here.

\section{Implications for understanding the plankton food web in the Sargasso Sea}

This study suggests that elevated vertical mixing rates may occur in association with specific hydrographic features within the frontal region of the STCZ in the Sargasso Sea. Several independent types of biological measurements indicate that this mixing may stimulate phytoplankton activity and influence plankton food web dynamics in the frontal region. We note as well that the greatest abundances of eel larvae reported by Munk et al. (2010) were found in association with a site within the frontal zone region where this study indicates elevated rates of vertical nutrient transport compared to the rest of the frontal region. Whether these specific hydrographic features are important for eel larvae ecology and, if so, whether the larvae only survive in or near these features or whether they accumulate (or hatch) in the vicinity of these features remains to be determined.

Acknowledgements. The present investigation was supported by Nordea Fund, Villum Kann Rasmussen Fund, The Carlsberg Foundation, Knud Petersen Fund, The Danish Expedition Fund, The Danish Research Council for Nature and Universe, The Danish Research Foundation and our respective institutions. The data were collected as part of the Galathea3 expedition under the auspices of the Danish Expedition Foundation. This is Galathea3 contribution no. P105.

\section{LITERATURE CITED}

> Andersen NG, Nielsen TG, Jakobsen HH, Munk P, Riemann L (2011) Distribution and production of plankton communities in the subtropical convergence zone of the Sargasso Sea. II. Protozooplankton and copepods. Mar Ecol Prog Ser 426:71-86

Arar EJ, Collins GB (1997) Method 445.0 In vitro determination of chlorophyll $a$ and pheophytin $a$ in marine and freshwater algae by fluorescence. US Environmental Protection Agency, www.epa.gov/microbes/m445_0.pdf

Beardall J, Young E, Roberts S (2001) Approaches for determining phytoplankton nutrient limitation. Aquat Sci 63: 44-69

> Cisewski B, Strass VH, Prandke H (2005) Upper-ocean vertical mixing in the Antarctic polar front zone. Deep-Sea Res II 52:1087-1108 
Collos Y, Jauzein C, Laabir M, Vaquer A (2013) Discrepencies between net particulate carbon production and ${ }^{13} \mathrm{C}$ labelled bicarbonate uptake by Alexandrium catonella (DINOPHYCEAE): grazing controls the balance between autotrophic and non autotrophic carbon acquisition. J Phycol 49:441-446

$>$ Cushman-Roisin B (1984) On the maintenance of the subtropical front and its associated countercurrent. J Phys Oceanogr 14:1179-1190

$>$ Dugdale RC, Goering JJ (1967) Uptake of new and regenerated forms of nitrogen in marine productivity. Limnol Oceanogr 12:196-206

Edler L (ed) (1979) Recommendations for marine biological studies in the Baltic Sea. Phytoplankton and chlorophyll. The Baltic Marine Biologists Publ No 5, p 1-38

Ferron B, Mercier H, Speer K (1998) Mixing in the Romanche fracture zone. J Phys Oceanogr 28:1929-1945

> Galbraith PS, Kelley DE (1996) Identifying overturns in CTD profiles. J Atmos Ocean Technol 13:688-702

Grasshoff K, Ehrhardt M, Kremling K (1983) Methods of seawater analysis, 2nd edn. Verlag Chemie, Weinheim

> Guidi L, Calil PHR, Duhamel S, Björkman KM and others (2012) Does eddy-eddy interaction control surface phytoplankton distribution and carbon export in the North Pacific Subtropical Gyre? J Geophys Res 117:G02024, doi:10.1029/2012JG001984

Hilligsøe KM, Richardson K, Bendtsen J, Sørensen L, Nielsen TG, Lyngsgaard MM (2011) Linking phytoplankton community size composition with temperature, plankton food web structure and sea-air CO2 flux. Deep-Sea Res I 58: 826-838

Jaccard P (1901) Étude comparative de la distribution florale dans une portion des Alpes et des Jura. Bull Soc Vaud Sci Nat 37:547-579

> Joyce TM, Hernandez-Guerra A, Smethie WM Jr (2001) Zonal circulation in the NW Atlantic and Caribbean from a meridional World Ocean Circulation Experiment hydrographic section at $66^{\circ} \mathrm{W}$. J Geophys Res 106(C10): 22095-22113

> Kleckner RD, McCleave JD (1988) The northern limit of spawning by Atlantis eels (Anguilla spp.) in the Sargasso Sea in relation to thermal fronts and surface-water masses. J Mar Res 46:647-667

Kleckner RD, McCleave JD, Wippelhauser GS (1983) Spawning of American eel, Anguilla rostrata, relative to thermal fronts in the Sargasso Sea. Environ Biol Fishes 9: 289-293

Kolber ZS, Prasil O, Falkowski PG (1998) Measurements of variable chlorophyll fluorescence using fast repetition rate techniques: defining methodology and experimental protocols. Biochem Biophys Acta-Bioenergetics 1367: 88-106

Kubokawa A, Inui T (1999) Subtropical countercurrent in an idealized ocean GCM. J Phys Oceanogr 29:1303-1313

Editorial responsibility: Antonio Bode, A Coruña, Spain
Lee TN, Johns WE, Zantopp RJ, Fillenbaum ER (1996) Moored observations of western boundary current variability and thermohaline circulation at $26.5^{\circ} \mathrm{N}$ in the subtropical North Atlantic. J Phys Oceanogr 26:962-983

> Leetmaa A, Voorhis AD (1978) Scales of motion in the subtropical convergence zone. J Geophys Res 83(C9): 4589-4592

McGillicuddy DJ Jr, Robinson AR, Siegel DA, Jannasch HW and others (1998) Influence of mesoscale eddies on new production in the Sargasso Sea. Nature 394:263-266

MODE group (1978) The mid-ocean dynamics experiment. Deep-Sea Res 25:859-910

Montoya JP, Carpenter EJ, Capone DG (2002) Nitrogen fixation and nitrogen isotope abundances in zooplankton of the oligotrophic North Atlantic. Limnol Oceanogr 47: 1617-1628

> Munk P, Hansen MM, Maes GE, Nielsen TG and others (2010) Oceanic fronts in the Sargasso Sea control the early life and drift of Atlantic eels. Proc R Soc Lond B Biol Sci 277:3593-3599

O'Connor BM, Fine RA, Olson DB (2005) A global comparison of subtropical underwater formation rates. Deep-Sea Res 52:1569-1590

Oschlies A, Garçon V (1998) Eddy-induced enhancement of primary production in a model of the North Atlantic Ocean. Nature 394:266-269

Pacanowski RC, Philander SGH (1981) Parameterization of vertical mixing in numerical models of the tropical ocean. J Phys Oceanogr 11:1443-1451

Platt T, Gallegos CL, Harrison WG (1980) Photoinhibition of photosynthesis in natural assemblages of marine phytoplankton. J Mar Res 38:687-701

> Riemann L, Nielsen TG, Kragh T, Richardson K, Parner H, Jakobsen HH, Munk P (2011) Distribution and production of plankton communities in the subtropical convergence zone of the Sargasso Sea. I. Phytoplankton and bacterioplankton. Mar Ecol Prog Ser 426:57-70

> Shcherbina AY, Gregg MC, Alford MH, Harcourt RR (2009) Characterizing thermohaline intrusions in the North Pacific Subtropical Frontal Zone. J Phys Oceanogr 39: 2735-2756

Steemann Nielsen E (1952) The use of radio-active carbon (C14) for measuring organic production in the sea. J Cons Int Explor Mer 18:117-140

Suggett DJ, Moore CM, Hickmann AE, Geider RJ (2009) Interpretation of fast repetition rate (FRR) fluorescence: signatures of phytoplankton community structure versus physiological state. Mar Ecol Prog Ser 376:1-19

Thorpe SA (1977) Turbulence and mixing in a Scottish loch. Philos Trans R Soc Lond Ser A 286:125-181

Ullman DS, Cornillon PC, Shan Z (2007) On the characteristics of subtropical fronts in the North Atlantic. J Geophys Res 112:C01010, doi:10.1029/2006JC003601

Utermöhl H (1958) Zur Vervollkommnung der quantitativen

Submitted: July 1, 2013; Accepted: February 17, 2014

Proofs received from author(s): May 5, 2014 